University at Buffalo School of Law

Digital Commons @ University at Buffalo School of Law

Journal Articles

Faculty Scholarship

$12-1-1972$

\title{
Conspiracy and the First Amendment
}

David B. Filvaroff

University at Buffalo School of Law

Follow this and additional works at: https://digitalcommons.law.buffalo.edu/journal_articles

Part of the Criminal Law Commons, and the First Amendment Commons

\section{Recommended Citation}

David B. Filvaroff, Conspiracy and the First Amendment, 121 U. Pa. L. Rev. 189 (1972).

Available at: https://digitalcommons.law.buffalo.edu/journal_articles/908

(C) 1972 Penn Law: Legal Scholarship Repository

\section{IN COPYRIGHT}

This Article is brought to you for free and open access by the Faculty Scholarship at Digital Commons @ University at Buffalo School of Law. It has been accepted for inclusion in Journal Articles by an authorized administrator of Digital Commons @ University at Buffalo School of Law. For more information, please contact lawscholar@buffalo.edu. 


\section{University of Pennsylvania Law Review FOUNDED 1852}

Formerly

American Law Register

VOLUME 121 DeCEMBer 1972 NUMBER 2

\section{CONSPIRACY AND THE FIRST AMENDMENT}

\section{David B. Filvaroff $\dagger$}

\section{INTRODUCTION}

The American legal system has not always responded well in times of deep intellectual, social, and political unrest. From $D e b s,{ }^{1}$ to the Japanese Relocation Cases, ${ }^{2}$ to Dennis, ${ }^{3}$ the courts have often leaned with, rather than against, the winds of orthodoxy and popular prejudice; they have tended to vindicate officialdom, particularly at the federal level, in its response to dissent or potential disloyalty. There have been exceptions, to be sure, but renunciation of abuse has often come only belatedly.

One of the legal weapons used in the traditionally unequal contest between government and dissent has been the doctrine of criminal conspiracy. While there has been much critical comment concerning the nature and uses of this historic crime, and while the literature surrounding the first amendment rights of free speech and association is certainly voluminous, relatively little careful study has been directed to the ways in which the two concepts converge and conflict when the government institutes prosecutions for conspiracy to commit speech or

$\dagger$ Visiting Professor of Law, University of Texas, S.B. 1953, University of Wisconsin; LL.B. 1958, Harvard University. Member, Ohio Bar.

1 There were two Debs cases in the Supreme Court. The first, growing out of a Pullman strike is In re Debs, 158 U.S. 564 (1895); the second, Debs v. United States, 249 U.S. 211 (1919), involves a conviction under the Espionage Act of 1917, ch. 30, 40 Stat. 217. Both are appropriate references here. As to the latter, see notes 52, 54 infra \& accompanying text.

2 Korematsu v. United States, 323 U.S. 214 (1944); Ex parte Endo, 323 U.S. 283 (1944); Hirabayashi v. United States, 320 U.S. 81 (1943). See generally Rostow, The Japanese American Cases-A Disaster, 54 YaLE L.J. 489 (1945). infra.

3 Dennis v. United States, 341 U.S. 494 (1951). See text accompanying notes 75-107 
speech-related offenses, an American variant of the "political crime." Indeed it is only fairly recently that commentators have begun to focus on the analytical questions involved in the use, in first amendment areas, of conspiracy doctrine developed in other, non-speech contexts. Perhaps the lag should not be too surprising. The law of free speech itself is a comparatively recent development in our constitutional history, by and large evolving only within the past half-century; and, notwithstanding criticism of conspiracy doctrine and its use, the crime is supported by a long tradition which seems to have muted constitutional challenge. The recent commentary particularly directed to the conspiracy-speech combination has been provoked by the trial of Dr. Spock and his alleged co-conspirators. ${ }^{4}$ United States v. Spock ${ }^{5}$ is only an example, however, and the issues there raised have pervasive implications in other related situations. ${ }^{6}$

Typically, when government acts against dissenters or the unorthodox, the rhetorical claims, if not the legal issues, are framed in terms of suppression of freedoms, particularly first amendment freedoms. By virtue of the very fact that the underlying issues are usually public, political, and controversial, they tend to generate responses founded on ideological, racial, or humanitarian grounds, and lead to attempts at association designed to strengthen the sources of resistance. The very effectiveness of almost any social or political effort in our highly organized and complex society-particularly when it challenges government policy or power-may well depend on its success in enlisting the aid of others of like mind. Thus, the allegedly offending action is often of a collective nature, involving a group which finds its origin in a shared opposition to official action or inaction.

Predictably, then, a charge of conspiracy comes to the prosecutorial mind as a base for the institution of criminal proceedings. The crime is obviously well adapted to the political and ideological uses to which it has been put. ${ }^{7}$ History has produced an offense which is both vague in its substance and malleable in its procedures. ${ }^{8}$ Its elements

4 See, e.g., Note, Conspiracy: Legitimate Instrument or an Unconstitutional Weapon?, 3 Colum. Survey of Human RIGHTS LAw 94 (1970); Note, The Logic of Conspiracy, 1970 WIs. L. REv. 191; Note, Conspiracy and the First Amendment, 79 YaLE L.J. 872 (1970).

5416 F.2d 165 (1st Cir. 1969).

6 Another recent case in which a speech conspiracy indictment was used is that of the "Chicago Seven," United States v. Dellinger, No. 69 CR 180 (N.D. III., Feb. 14-15, 1970), rev'd, No. 18,295 (7th Cir., Nov. 21, 1972), noted in 69 MiCE. L. Rev. 1549 (1971), in which the defendants were charged, inter alia, with conspiracy to cross state lines with intent to incite a riot. See 18 U.S.C. \& 2101 (1970).

7 Even the commentators to the A.L.I. Model Penal Code, which defends and carries forward much of traditional conspiracy doctrine, feel it necessary to pay verbal deference to such special grievances as those based on the early condemnation of the labor union as a "criminal conspiracy and the use of the charge against political offenders . ..." Model Penal Code \$ 5.03, Comment at 96 (Tent. Draft No. 10, 1960).

8 Originating in the 13 th century as a device to deal with what we now call malicious 
can be stated with deceptive simplicity. ${ }^{9}$ Conviction requires agreement or combination, illegal means or illegal ends, and some sort of improper motive or intent. No overt act in furtherance of the agreement is necessary except as required by the particular statute under which the charge is laid, and even then there is confusion about its significance: whether as an essential element of the crime or as merely part of the evidence of conspiracy. ${ }^{10}$ It is the agreement itself which is the touchstone of illegality, irrespective of whether or not efforts have actually been made to implement prohibited objectives, and apparently without regard even to whether the combination is capable of achieving them. The very existence of group purpose is enough, without more, to support the presumption of societal danger warranting criminal punishment.

Reliance on conspiracy holds a number of familiar attractions for the prosecutor. The application of the conspiracy label serves to brand the opposing group with an image of secrecy and evil plotting that tends to exaggerate the threat of the challenged conduct and heightens apprehensions latent in the community. ${ }^{11}$ More directly, the charge of

prosecution, the crime of conspiracy, within a few hundred years, came to include combinations whose objectives were not limited to misuse of the courts or the litigative process. Once freed of its narrower beginnings, conspiracy was quickly associated with control and punishment of economic and political activities. See generally Sayre, Criminal Conspiracy, 35 HARV. L. REv. 393 (1922).

${ }^{3}$ Attempts to describe the crime in specific terms have proven extremely difficult, if not completely frustrating. Justice Jackson concluded that the "modern crime of conspiracy is so vague that it almost defies definition. Despite certain elementary and essential elements, it also, chameleon-like, takes on a special coloration from each of the many independent offenses on which it may be overlaid. It is always 'predominately mental in composition' because it consists primarily of a meeting of minds and an intent." Krulewitch v. United States, 336 U.S. 440, 446-48 (1949) (concurring opinion) (citations omitted). One commentator has declared: "In the long category of crimes there is none, not excepting criminal attempt, more difficult to confine within the boundaries of definitive statement than conspiracy." Harno, Intent in Criminal Conspiracy, 89 U. PA. L. REv. 624, 624 (1941). An earlier writer was led to assert that "no intelligible definition of "conspiracy' has yet been established." R.S. WRIGHT, THE LAw OF CRTMINAT CONSPIRACIES AND AGREEMENTS 11 (1887).

A facile-and non-helpful-try at description was made by Justice Holmes in United States v. Kissel, 218 U.S. 601, 608 (1910), where he labeled conspiracy "a partnership in criminal purposes."

${ }^{10}$ See Yates v. United States, 354 U.S. 298, 333-34 (1957); Hyde v. United States, 225 U.S. 347 (1912) (majority and dissenting opinions); Developments in the Law: Criminal Conspiracy, 72 HARv. L. REv. 920, 945-48 (1959) [hereinafter cited as Developments].

11 An interesting article discussing conspiracy in psychiatric terms suggests that invocation of the concept plays on the inherent fears, suspicions, and insecurities of both individuals and groups. Katz, $A$ Psycho-Analytic Peek at Conspiracy, 20 BuFralo I. REv. 239 (1970). Not only is the "notion of conspiracy . . . useful in 'explaining" the anxiety one feels toward otherwise ambiguous events (e.g., the Kennedy assassination and campus disruptions)," $i d$. 249, but, one might add, also in accounting for the existence of dissent and opposition to government policy. As the author notes:

The instinctual appeal of conspiracy means that if people are given any sugges-

tion that a conspiracy exists their psychological matrix of expectations shifts the

burden of proof to the extent of creating in their own minds a presumption

in favor of the reality of such a conspiracy. In other words, people seem more

ready to believe an allegation of conspiracy ("there is more to this than meets

the eye") than they are to accept apparent explanations.

Id. 345-46. The result suggests why conspiracy is so useful in the political case:

Quite apart from the effect of this presumption on the outcome of actual 
conspiracy gives the government substantive flexibility and ease of proof as well as specific procedural advantages which can operate to the substantial prejudice of the defendants. The rule against admission of hearsay evidence, for example, is relaxed to allow the acts and alleged words of co-conspirators (whether or not co-defendants) to be used against each other, even when cross-examination of the declarant is possible. ${ }^{12}$ The regular order of proof is eased and the prosecution afforded great freedom in making its case. ${ }^{13}$ "As a practical matter, the accused often is confronted with a hodgepodge of acts and statements by others which he may never have authorized or intended or even known about, but which help to persuade the jury of existence of the conspiracy itself. In other words, a conspiracy often is proved by evidence that is admissible only upon the assumption that conspiracy existed. The naive assumption that prejudicial effects can be overcome by instruction to the jury . . . all practicing lawyers know to be unmitigated fiction."14

There is substantial danger that any given defendant will become the victim of guilt by association. Not only does the very presence of all the defendants together in the courtroom itself suggest their combination and complicity, but there usually will be some evidence of illegality by someone and, given the lengthy trial and voluminous record typical of conspiracy proceedings, ${ }^{15}$ the jury will find it hard to sort out the individual merits of the case against each accused. ${ }^{16}$ The

litigation, it has significant political and social consequences. By employing the rhetoric of plot or conspiracy, any group ... can generate substantial apprehension, and use the anxiety thus generated to support policy decisions which might otherwise not stand up against rational argument.

Id. 246. In Krulewitch v. United States, 336 U.S. 440, 448 (1949) (concurring opinion), Justice Jackson stated:

The crime comes down to us wrapped in vague but unpleasant connotations. It sounds historical undertones of treachery, secret plotting and violence on a scale that menaces social stability and the security of the state itself. "Privy conspiracy" ranks with sedition and rebellion in the Litany's prayer for deliverance.

12 For a discussion of the conspiracy exception to the general rule regarding the admission of hearsay evidence, see Krulewitch v. United States, 336 U.S. 440 (1949); Levie, Hearsay and Conspiracy, 52 MICH. L. REv. 1159 (1954).

13 Developments, supra note 10, at 984. See also Goldstein, Conspiracy to Defraud the United States, 68 YALE L.J. 405, 412 (1959).

14 Krulewitch v. United States, 336 U.S. 440, 453 (1949) (concurring opinion) (citations omitted).

15 Conspiracy cases-especially political ones-seem to have a way of producing unusually lengthy trials and trial records. This can hardly make the jury's task easier or more likely to produce a fair verdict. For example, the case of the "Chicago 7," supra note 6 , took over four months to present; more than 200 witnesses were called and the transcript ran in excess of 22,000 pages.

16 An additional advantage to the government in a conspiracy prosecution is the wide latitude in choosing the court in which the case will be tried. Venue in a conspiracy trial will lie in the district where the agreement was formed, or where any of the overt acts of any of the co-conspirators occurred. See Hyde v. United States, 225 U.S. 347, 356-67 (1912). Thus, for example, the government could choose to try the Berrigan conspiracy in 
use of the conspiracy indictment in order to obtain prosecutorial advantage, even as applied to non-political cases, has met serious criticism from legal scholars: "[T] he general critique has pointed to the danger of a dragnet in the broad, uncertain ground of liability, the wholesale joinder of defendants, the imposition of vicarious responsibility, the relaxation of the rules of evidence, or some or all combined." ${ }^{\prime 17}$ Misuse of the conspiracy charge and the panoply of governmental advantages in conspiracy trials led Mr. Justice Jackson in his noted concurrence in Krulewitch $v$. United States, ${ }^{18}$ to conclude that the "loose practice as to this offense constitutes a serious threat to fairness in our administration of justice."

The risk of prejudice at the trial is accentuated when the case involves dissenters whose views are in themselves likely to be distasteful to both judge and jury. The threat of conspiracy indictments in such cases also has an important effect which works outside the courtroom. While the danger of an indictment for conspiracy, as an alternative or addition to an indictment for a substantive speech crime, may have little or no "chilling effect" on the first amendment rights of those who are determined to speak, it is a significant deterrent to the less hardy-those who would assist or aid others to speak. By virtue of an alleged "agreement" that a speech should be made, they may become indictable as co-conspirators with the speaker. Even if such"third parties escape indictment, they run the risk that their words and actions will be used in the government's case against those who are defendants.

In such a setting-where the dragnet charge is so useful a tool to punish those who express critical, unorthodox, or unpopular viewsit is crucial that the propriety of reliance on the charge of conspiracy to commit a speech crime be given the closest scrutiny. Peculiarly subject to abuse in even the run-of-the-mine criminal case, the conspiracy device - the "darling of the modern prosecutor's nursery"19_demands heightened critical analysis when basic political rights may be at stake.

\section{Conspiracy: The General Justification}

Criminal conspiracy is usually categorized and treated as an inchoate offense-as a device designed and used to thwart incipient substantive evil. But this single conception does not comport with its

Harrisburg, $\mathrm{Pa}$., and thereby avoid other more accessible Eastern cities with a climate potentially more hospitable to the anti-war movement and with facilities better adapted to serving the press and television corps.

17 Moder Penal Code \$ 5.03, Comment at 96 (Tent. Draft No. 10, 1960).

18336 U.S. 440, 452 (1949). Jackson's opinion was joined by Justices Frankfurter and Murphy.

19 Judge Learned Hand in Harrison v. United States, 7 F.2d 259, 263 (2d Cir. 1925). 
practical use. ${ }^{20}$ The conspiracy charge is perhaps pressed even more often after completion of a substantive offense than before. The rationale of each aspect of the offense-conspiracy as the punishable precursor of substantive criminal conduct and as an additional part of the indictment even after achievement or attempted achievement of its criminal objectives-is relevant to understanding its application to speech.

\section{A. The Inchoate Crime}

Normally, the criminal law is concerned only with punishment of actions which have produced harmful consequences to an individual or to society. The law, by and large, has focused on conduct which constitutes a completed offense and has not sought to punish planning or preparation, much less intent standing alone. The interests involved in such a resolution are fairly clear-cut and seemingly well-settled. Although one might argue that prevention of crime could be better accomplished by punishing still nascent offenses, if not intent itself, there are strong countervailing considerations. The possible gains are generally thought to be outweighed by the likelihood of restricting otherwise innocent activities and inhibiting the exercise of personal freedoms, and by the serious risk of error in making the necessarily subtle and difficult factual determinations that would be required. Even so, in a few instances, the law has allowed prosecution for conduct occurring earlier in the causal chain. Thus we have the so-called inchoate crimes: attempt, incitement (or solicitation), and conspiracy are the classic examples. Each reaches back in time, prior to the completion of the substantive offense, and seeks to punish for something less than effectuation of the ultimate harm.

Attempt is closest in both temporal and physical proximity to the final offense and indeed may be separated from it only by the actor's own ineptitude or some fortuitous intervention that precludes success. But, still, attempt does require more than mere preparation; there must be an effort to perpetrate the substantive crime. ${ }^{21}$

Incitement calls for no more than the effort to induce another to

20 Thus the A.L.I. Model Penal Code groups conspiracy in article 5, entitled

"Inchoate Crimes," but declares:

It is worthwhile to note preliminarily that conspiracy as an offense has two different aspects, reflecting different functions it serves in the legal system. In the first place, it is an inchoate crime, complementing the provisions dealing with attempt and solicitation in reaching preparatory conduct before it has matured into commission of a substantive offense. Secondly, it is a means of striking against the special danger incident to a group activity, facilitating prosecution of the group and yielding a basis for imposing added penalties when combination is involved.

Model Penat Code $\S 5.03$, Comment at 96 (Tent. Draft No. 10, 1960).

21 See R. Perkins, Crimmial Law 552, 557, 561 (2d ed. 1969). 
commit the criminal act and it matters not whether the other actually agrees to do so or even makes an attempt; purposeful communication designed to procure commission of the substantive offense is the essential ingredient. ${ }^{22}$

Among the trio, conspiracy is most distant from the completed harm. In practice, the dimensions of the conspiracy concept have become quite flexible and even the requirement that there be an overt act has lost substantive significance. ${ }^{23}$ As a result, conspiracy prescribes punishment for little more than state of mind. Though the liturgy of courts and commentators recites the proposition that the agreement represents conduct, not merely state of mind, agreement in reality is no more than shared state of mind; $;^{24}$ and when one accepts the principle, as the courts have done, that the agreement can be implicit as well as explicit, and that the trier of fact can infer its existence from still other facts, ${ }^{25}$ the element of conduct shrinks to still smaller dimensions.

The rationale of making conspiracy a crime, it is said, is the increased danger to society from the existence of a group bent on criminal activity. The incremental threat posed by the combination is asserted to support the proscription even though the same threatened conduct and state of mind in a single individual would not be punishable. The justification seems based on a set of factually unproven and perhaps undemonstrable assumptions: that the combination increases the likelihood that the contemplated criminal activity will actually occur and that the venture will be successful; that the conspirators will reinforce each other in strength of purpose and intent; that they will work to dispel each other's doubts; that they will find added strength and effectiveness in numbers and in the division and specialization of labor they

22 Id. $582,584$.

23 At common law, no overt act was even required. See Fiswick v. United States, 329 U.S. 211, 216 n.4 (1946); Hyde v. United States, 225 U.S. 347, 359 (1912). The rule has been carried forward so that the government need not prove an overt act unless compelled by the statute under which the charge is laid. No overt act was required for conviction in Spock.

Even when proof of an overt act is necessary, it "has seldom materially increased the difficulty of securing convictions for conspiracy." Developments, supra note 10, at 946. As the Supreme Court said in Yates v. United States, 354 U.S. 298, 334 (1957):

It is not necessary that an overt act be the substantive crime charged in the

indictment as the object of the conspiracy. . . . Nor, indeed, need such an act, taken by itself, even be criminal in character.

The act can thus be "relatively minor," even a telephone call, and may consist of a failure to do something, so long as it is in furtherance of the conspiracy. See Developments, supra, at 946. "The courts somehow discover an overt act in the slightest action on the part of the conspirators." Pollack, Common Law Conspiracy, 35 GEO. L.J. 328, 338 (1947).

24 See Developments, supra note 10, at 925-27; Goldstein, supra note 13, at 409-10.

25 See, e.g., American Tobacco Co. v. United States, 328 U.S. 781, 809-10 (1946); Direct Sales Co. v. United States, 319 U.S. 703, 714 (1943). 
allow; that the dimension and complexity of the harm will be multiplied by the increase in participants; and that they will be better able to utilize, dispose of, or benefit from the fruits of their crime, thereby adding to the difficulty of discovery and ultimate punishment. ${ }^{28}$

Some or all of this may be true in given cases; but as one critic of the doctrine has written:

Though these assumed dangers from conspiracy have a romantically individualistic ring, they have never been verified empirically. It is hardly likely that a search for such verification would end in support of Holdsworth's suggestion that combination alone is inherently dangerous. This view is immediately refuted by reference to our own society, which is grounded in organization and agreement. More likely, empirical investigation would disclose that there is as much reason to believe that a large number of participants will increase the prospect that the plan will be leaked as that it will be kept secret; or that the persons involved will share their uncertainties and dissuade each other as that each will stiffen the others' determination. Most probably, however, the factors ordinarily mentioned as warranting the crime of conspiracy would be found to add to the danger to be expected from a group in certain situations and not in others; the goals of the group and the personalities of its members would make any generalization unsafe and hence require some other explanation for treating conspiracy as a separate crime in all cases. ${ }^{27}$

If there is reason to question the unrefined generalization that group planning is inherently more dangerous than the planning of a crime by an individual, there is also reason to question the assumption that the mere possibility of prosecution for conspiracy works any effective deterrent, in and of itself, beyond that achieved by the existence of the penalties for actual commission of the substantive crime which is the objective of the combination. It is unlikely that one who is willing to risk the punishment established for success in achieving the criminal purpose of the conspiracy will be additionally deterred by the threat

26 See, e.g., Callanan v. United States, 364 U.S. 587, 593-94 (1961); Note, The Conspiracy Dilemma: Prosecution of Group Crime or Protection of Individual Defendants, 62 HARV. L. REv. 276, 283-84 (1948). The rationale is not of recent origin, though it has rarely been questioned. For an example of an early American case explicating some of the asserted distinctions between group and individual action, see Commonwealth $v$. Carlisle, 36 Bright 38, 41 (1821):

The effort of an individual to disturb the equilibrium can never be perceptible, nor carry the operation of his interest, or that of another individual, beyond the limit of fair competition; but the increase of power by combination of means, being in geometrical proportion to the number concerned, an association may be able to give an impulse, not only oppressive to individuals, but mischievous to the public at large; and it is the employment of an engine so powerful and dangerous, that gives criminality to an act that would be perfectly innocent, at least in a legal view, when done by an individual.

27 Goldstein, supra note 13, at 414 . 
of punishment merely for agreeing in advance to so act. Even the proposed Model Penal Code, which would preserve most of extant conspiracy law, concedes as much. ${ }^{28}$ Still the extension of the criminal law to the inchoate offense of conspiracy does permit the authorities to intervene, if they discover the offending plan, without awaiting the ultimate event. Obviously, the greater the reality and dimensions of the anticipated evil, the more plausible is the effort to forestall it. By the same token, if the danger is of a lesser order, the countervailing factors noted earlier assume greater weight in the balance.

These considerations have particular pertinence in the context of speech crimes, not only because the need for early restraint may be far from compelling, but because of the involvement of the first amendment. Continued reliance on conspiracy as an inchoate offense in speech cases should take account of the extent to which it is actually effective or necessary to prevent the evil which the conspirators would seek to achieve. And, beyond the question of pragmatic need, there are serious conceptual and constitutional problems presented when conspiracy is treated as an inchoate offense in application to speech. ${ }^{29}$

\section{B. The Crime of Complicity}

Theoretically, at least, the main use of conspiracy doctrine should be against combinations which have not yet moved to achieve their criminal purposes-against conspiracies which are still executory in whole or substantial part. Certainly the rationale that conspiracy is necessary to allow the government to abort intended criminal conduct before it matures into a committed substantive offense fails to justify resort to conspiracy once the illegal plans have been realized and prosecution for the substantive offense is possible. Nonetheless, parallel substantive and conspiracy counts are common prosecutorial practice and it may be as likely that the former will be omitted as the latter when either or both are legally possible in any given case. ${ }^{30}$

In those instances in which the substantive crime has already occurred, reliance on conspiracy works a change in both the nature and purpose of the prosecution. Conspiracy ceases to be used as a device to punish or thwart inchoate offenses and takes on a different coloration. For principals in the completed offense, it does the work (in alternative

28 Moder Penal Code art. 5, Comment at 24 (Tent. Draft No. 10, 1960).

20 See text accompanying notes 161-94 infra.

30 Thus, Justice Jackson was moved to warn in his concurring opinion in Krulewitch v. United States, 336 U.S. $440,445-46$ (1949), that "the unavailing protest of courts against the growing habit to indict for conspiracy in lieu of prosecuting for the substantive offense itself, or in addition thereto, suggests that loose practice as to this offense constitutes a serious threat to fairness in our administration of justice." 
form) of the substantive charge; ${ }^{31}$ for more peripheral figures, it operates as a charge of complicity in the completed crime.

It is asserted that in some instances the charge of conspiracy is essential in order to reach those who bear a significant responsibility for criminal activity, but whose tangible contribution is difficult to prove by usual means. The example commonly given is that of organized crime, where the planner, the initiator, or the beneficiary of the criminal act is a higher-up, a key figure in the organization whose power, influence, and importance relieve him of obvious participation in the actual commission, but not of culpability. ${ }^{32}$ The broad-ranging conspiracy trial with multiple defendants, it is said, provides a unique opportunity to probe the dimensions and workings of a complex criminal design..$^{33}$

On one level, the use of conspiracy to reach both principal and accomplice in completed criminal action is less onerous than its employment to punish the unexecuted agreement. Doubt as to whether, absent discovery and prosecution, the alleged conspirators would in fact have moved beyond planning or preparation is removed. Concern about whether punishment is being imposed for mere intent alone is alleviated because the actual effort to fulfill the conspiratorial objective serves as guarantor of the defendants' firmness of purpose and commitment, a function that might have been served in part by the overt act requirement had its content not been so significantly diluted. ${ }^{34}$ There still remains, however, the familiar danger that the very latitude and looseness of the conspiracy trial may prejudice individual defendants. This risk may be especially great in cases involving speech conspiracies and there is grave doubt that it can be justified by society's legitimate needs.

\section{Conspiracy and Speech Crimes: A Preliminary Analysis}

Much of the difficulty in grappling with the concept of conspiracy to commit a speech crime is a function of the almost total failure of the

31 The reasons for such use are not hard to fathom. For the prosecutor, the conspiracy case, with all its procedural and evidentiary freedoms, brings substantial tactical advantages at trial. See notes 11-19 supra \& accompanying text.

32 An early version of proposed revision of federal criminal law suggested, however, that "traditional conspiracy notions" were "outdated when applied to an organized criminal business" and recommended a specially drafted provision to deal with organized crime. The final report of the study commission "shelved" the preliminary proposal in favor of imposition of increased penalties for leaders of organized crime. Compare National Commisston on Reform of Federal Crimtinal Laws, Proposed New Federat Crmmtnal Code $\S 1005$, Comment at 68 (Study Draft 1970) with National Comarission on Reform of Federal Crtminal Laws, Proposed New Federal Crmminal CODE $\$ 1004$, Comment at 72 (Final Report 1971). For another example of the use of conspiracy to reach the planners or initiators of criminal activity, see 18 U.S.C. $\$ \S 2101$, 2102 (1970) (punishing interstate travel with intent to incite a riot).

33 See, e.g., Moder Penal Code \& 5003, Comment at 98 (Tent. Draft No. 10, 1960). 34 See note 23 supra. 
courts to distinguish between the possible uses of the charge: between conspiracy framed as an inchoate offense before any illegal speech has occurred and its use as a device to prosecute for past illegal utterances. The leading cases involve (or the courts seem to assume they involve) illegal incitement or advocacy which has already occurred, thus suggesting that the conspiracy allegation is relied upon to charge complicity in another completed offense. Nonetheless, the decisions for the most part treat and justify their reliance on conspiracy as if it were being used as an inchoate offense.

So conceived, there is a deep-seated conflict between traditional conspiracy doctrine and the law of free speech. As noted, conspiracy alone requires only agreement, intent, and illegal purpose. When speech is involved, however, the first amendment requires more. There must be a sufficient governmental interest to warrant suppression. ${ }^{35}$ Even then, only advocacy of action, actual incitement itself, may be barred. ${ }^{36}$ Finally, some measure must be taken of the reality of the threat posed by the challenged speech. ${ }^{37}$

When the two doctrines are fused in the context of speech-conspiracy, one would suppose that the constitutional demands would be read to override the more elastic and far-reaching common law concepts-that conspiracy doctrine would be strictly measured against first amendment requirements and the application of traditional conspiracy rules either barred or neatly tailored to preclude intrusion into prohibited areas. This has not been the case. Instead, the courts have created a patchwork. Providing little by way of analysis, they have treated the usual criminal conspiracy rules-developed in other contexts-as largely transferrable to speech cases. With the exception of imprecations about the need to find specific intent, the decisions have done little more than prescribe a meld of basically incompatible legal concepts, leaving both first amendment and conspiracy rules to a dangerous and inarticulate reconciliation in practice.

By definition, proof of criminal conspiracy is complete, and conviction warranted, without any showing of illegal action beyond the agreement itself. Thus, in the case of an alleged conspiracy to incite, for example, there would be no need to show that the defendants delivered themselves of any illegal words; the existence of the combined intent to do so would suffice. Given the fact of agreement, there would be no occasion to await the apprehended danger-prosecution could be text.

35 Dennis v. United States, 341 U.S. 494 (1951). See note 80 infra \& accompanying

36 Yates v. United States, 354 U.S. 298 (1957).

37 Dennis v. United States, 341 U.S. 494 (1951). See Brandenburg v. Ohio, 395 U.S. 444 (1969). 
initiated before any inflammatory speech were made, before any "illegal" tract or pamphlet were written or published, and before any threatening demonstration were held. Even where the applicable criminal conspiracy statute calls for proof of an overt act, there is no requirement that it be the illegal incitement itself or, indeed, that it be illegal conduct of any kind.

Respect for first amendment standards would seem to require that criminality turn on more than a bare prediction of both the nature and probable consequences of words not yet uttered. Even where speech has crystallized the difficulties of reconciling the first amendment and statutes proscribing advocacy are inordinate. One would not expect the courts to compound these difficulties and to undertake appraisal of projected or future advocacy. Yet, with but slight variation, the language of the speech-conspiracy decisions appears to assume that this may be done.

The case to be made against the speech-conspiracy combination is a strong one, in both constitutional and practical terms. Before subjecting it to more particularistic exposition and analysis, however, it is useful to trace the American application of conspiracy doctrine to speech and to try to discover how and why the courts have left the law in such an unsatisfactory state. Several reasons may be ventured. The first Supreme Court cases upholding the constitutionality of the combination were decided before the full body of first amendment law had itself developed; indeed, they were handed down almost concurrently with the beginnings of free speech doctrine. Initially, therefore, there was simply no need to confront or rationalize two inconsistent approaches. Perhaps inhibited by the hoary tradition and rhetoric which surrounded conspiracy, courts later built upon this narrow foundation and did little more than condone reliance on the combination.

Another factor also may have led to faulty analysis of conspiracy to commit a speech crime. Not surprisingly, most of the American speech-crime conspiracy law has been developed in times of national tension. Each of the key decisions involved dissenters whose political deviance tended to magnify their perceived threat to national security, thereby probably helping to propel the courts to pro-government results. The initial Supreme Court cases in the area arose during the height of patriotic fervor in World War I and involved challenges to the country's military involvement abroad. The anti-communist paranoia following the Second World War produced another series of prosecutions which required the Court to confront the problems presented by the concept of a conspiracy to commit a speech crime. And the Spock case itself was an outgrowth of the passions engendered by the nation's 
commitment in Viet Nam. In none of these decisions, all of which approved the speech-conspiracy combination, did the Court deal adequately with the conceptual and practical issues raised by the nature of the prosecution. Indeed, the opinions more often added confusion by their failure to examine the sources and nature of the conspiracy doctrines they imported into the speech area.

\section{THE WORLd WAR I EXPERIENCE}

The modern history of speech-conspiracy law in the United States began with a group of cases now remembered primarily for the eloquence of the Holmes-Brandeis dissents they engendered. It is little noticed today that these were the decisions which first tested traditional conspiracy law in the speech area and found the combination constitutional. The union was effected easily and with little analysis. This was perhaps expectable given the then primitive state of free speech doctrine.

The generating decisions in the Supreme Court are now barely fifty years old, and they have not aged well. They are a series of nine decisions, all but two of which were handed down in a single twelvemonth period spanning two terms of the Court. ${ }^{38}$ All but on ${ }^{39}$ arose out of federal prosecutions brought during the First World War charging violation of the Espionage Act of $1917 .^{40}$ Several of the opinions addressed indictments joining substantive and conspiracy counts, ${ }^{41}$ and all but possibly the first and last involved alleged conspiracies in which the challenged speech, whether written or spoken, had already taken place; that is, they involved executed, or at least partially executed, conspiracies. In each of these, then, the conspiracy charge was not essential to prosecution, for the "attempt" or "incitement" or "advocacy" was readily available as a basis for conviction of the defendants, typically socialists, anarchists, or other political dissenters.

The 1919-1920 cases not only established the constitutionality

38 Goldman v. United States, 245 U.S. 474 (1918); Schenck v. United States, 249 U.S. 47 (1919); Frohwerk v. United States, 249 U.S. 204 (1919); Debs v. United States, 249 U.S. 211 (1919); Abrams v. United States, 250 U.S. 616 (1919); Stilson v. United States, 250 U.S. 583 (1919); Shaefer v. United States, 251 U.S. 466 (1920); Pierce v. United States, 252 U.S. 239 (1920); O'Connell v. United States, 253 U.S. 142 (1920).

39 Goldman involved a conspiracy to violate provisions of the World War I Selective Service Act, Act of May 18, 1917, ch. 15, 40 Stat. 76. Stilson and O'Connell both charged a conspiracy to violate that Act as well as the Espionage Act, Act of June 15, 1917, ch. 30,40 Stat. 217.

40 Act of June 15, 1917, ch. 30, 40 Stat. 217. Title I, $\S 3$ of the Act prohibited causing or attempting to cause "insubordination, disloyalty, mutiny, or refusal of duty, in the military or naval forces of the United States" or obstructing "the recruiting or enlistment service of the United States." Title I, \& 4 of the Act punished conspiracies to violate $\$ 3$. charged.

41 In fact, Debs was the only case in the series in which a conspiracy was not 
of the concept of a conspiracy to commit a speech crime, but they also articulated the beginnings, mainly in Holmes' dissents, of the development of a concept of specific intent as an element of the offense -a theme repeated later with even more emphasis in the Communist Party cases, coming to precise application in the majority opinion in Spock.

In Goldman v. United States, ${ }^{42}$ the Court unanimously affirmed the conviction of Emma Goldman and Alexander Berkman upon a single count indictment charging them with conspiracy to "induce" others to fail to register for the draft. Though Chief Justice White's opinion concludes that the evidence was sufficient to take the case to the jury, the nature of the defendants' conduct was not disclosed. There was no mention of the first amendment. Indeed, apart from declaring that questions as to the constitutionality of the Draft Act itself had been resolved a week earlier by the decision in Arver $v$. United States, ${ }^{43}$ there was no suggestion that the case even raised any fundamental issue. The opinion merely adverted to "settled doctrine" that conspiracy is "in and of itself inherently and substantively a crime punishable as such irrespective of whether the result of the conspiracy has been to accomplish its illegal end." 44 The focus of the brief opinion was primarily upon the evidentiary question and the rigors of criminal conspiracy law.

The series of Espionage Act cases began a year later with Schenck v. United States. ${ }^{45}$ Schenck and another were convicted on a three count indictment for having printed and circulated a leaflet challenging military conscription. The first count-which drew the primary attention of the Supreme Court-charged a conspiracy to violate the Espionage Act "by causing and attempting to cause insubordination, \&c., in the military and naval forces ... and to obstruct the recruiting and enlistment service ... when the United States was at war with the German Empire ...." ."46

Schenck and his co-defendants specifically asserted the first amendment as a defense. In rejecting the claim and affirming the convictions, Holmes fashioned the "clear and present danger" test."7

42245 U.S. 474 (1918).

43245 U.S. 366 (1918).

44245 U.S. at 477 . To support this proposition, the Court referred only to one case, United States v. Rabinowich, 238 U.S. 78 (1915) (conspiracy to violate the Bankruptcy Act) "and authorities there cited." 245 U.S. at 477.

45249 U.S. 47 (1919).

46 Id. at $48-49$.

47 The question in every case is whether the words are used in such circumstances and are of such a nature as to create a clear and present danger that they will bring about the substantive evils that Congress has a right to prevent.

Id. at 52. The test has been both praised and condemned. Compare Z, Chafee, Fres 
Reasoning that there would be no difficulty in applying criminal sanctions if the defendants" words had produced an "actual obstruction of the recruiting service," he noted that section 4 of the Espionage Act expressly proscribed conspiracies to obstruct, as well as actual obstruction, and went on to declare:

If the act, (speaking, or circulating a paper,) its tendency and the intent with which it is done are the same, we perceive no ground for saying that success alone warrants making the act a crime. ${ }^{48}$

And so, in a few sentences, citing Goldman as authority, ${ }^{49}$ the Court completed the meld of speech crimes and conspiracy. Holmes made no real attempt to apply the clear and present danger test to the facts of the case, but merely declared it to be the applicable standard, apparently self-evidently met. As for the requisite intent, it was seemingly enough to note that the leaflet "would not have been sent unless it had been intended to have some effect, and we do not see what effect it could be expected to have upon persons subject to the draft except to influence them to obstruct the carrying of it out." 50 The theme was a typical application of traditional common law doctrine that a man is responsible for and deemed to intend the natural and probable consequences of his acts.

Schenck was followed a week later by Frohwerk $v$. United States, ${ }^{51}$ and Debs v. United States. ${ }^{52}$ In both cases, Holmes again wrote for a unanimous Court to affirm convictions under the Espionage Act. The crucial charge in Frohwerk was conspiracy to violate the statute, with the overt acts being the preparation and circulation of a dozen articles in the Missouri Staats Zeitung, an ethnically-directed newspaper of pro-German sympathies published by the defendant and his alleged coconspirator. To the contention that the first count lacked an allegation of the means by which the conspiracy was to be carried out, Holmes

Speech IN The UnIted States 82 (1941) with A. Merklejomn, Free Speech and Its ReLation to SELF-Governarent 29 (1948). Justice Jackson called the doctrine "the only original judicial thought on the subject." Dennis v. United States, 341 U.S. 494, 561, 567 n.9 (1951) (concurring opinion). Professor Freund has written that the clear and present danger test calls for an "oversimplified judgment" and that the very words "tend to convey a delusion of certitude." P. FreUnd, ON UNDERSTANDIng tHe SUPREME COURT 27-28 (1949). The literature on the subject is, predictably, voluminous.

48249 U.S. at 52.

$49 \mathrm{Had}$ Goldman been only slightly more expansive in its discussion, it might have been treated as wholly controlling and the now renowned paragraph in Schenck might never have been written. Referring to Goldman, Holmes declared, "Indeed that case might be said to dispose of the present contention if the precedent covers all media concludendi. But as the right to free speech was not referred to specially, we have thought fit to add a few words." Id. at 52 .

$50 \mathrm{Id}$. at 51.

51249 U.S. 204 (1919).

62249 U.S. 211 (1919). 
simply declared that "a conspiracy to obstruct recruiting would be criminal even if no means were agreed upon specifically by which to accomplish the intent. It is enough if the parties agreed to set to work for that common purpose."53 Again, as in Schenck, Holmes had no difficulty whatsoever in applying traditional common law conceptions of conspiracy to the speech case- the agreement alone was enough, he ruled, to justify the criminal label.

Common to Schenck, Frohwerk, and Debs ${ }^{54}$ (the only case of the series not involving a charge of conspiracy), was their simplistic treatment of intent and effect-probable consequences turn on what the speaker is assumed to have intended, with intent to be inferred, if need be, from his words alone; and probable effect follows on the heels of intent without examination of the specific context in which the words were spoken or the audience to which directed. (The only possible exception was in Schenck's brief allusion to the fact that the leaflets there were specifically directed to men subject to the draft or already called.) It is surprising that Holmes, as the author of all three opinions and of the clear and present danger test itself, paid so little attention in these initial cases to the very factors which he and Brandeis raise so vigorously in dissent in the immediately succeeding decisions; given his own handbook in Schenck, Frohwerk, and Debs, his sense of alarm and dismay at the uses to which Schenck is put in the later cases seems somewhat out of place. ${ }^{55}$

Abrams v. United States, ${ }^{56}$ decided early in the following term, was the first Espionage Act case to split the Court. Abrams and four others were prosecuted as a result of having published 5000 circulars, printed in English and Yiddish, which they distributed in New York City, "some by throwing them from a window of a building where one of the defendants was employed and others secretly." Directed to Russian emigrees and others, the text strongly criticized Allied intervention in Russia, encouraged support of the Soviet revolution, and called for a general strike. Four of the defendants had taken the stand at trial and, as Justice Clarke's opinion for the Court gratuitously pointed out, all

53249 U.S. at 209.

54 In Debs, a non-conspiracy conviction under the Act was based on delivery of a single speech. Debs was charged with causing, inciting and attempting to cause and incite insubordination, etc., in the armed forces, and with obstruction and attempted obstruction of recruitment and enlistment services.

55 For the view that Justice Holmes was not often particularly responsive to civil liberties, see Rogat, Mr. Justice Holmes: A Dissenting Opinion (pts, 1-2), 15 Sran. L. REv. 3, 254 (1963).

56250 U.S. 616 (1919).

67 Id. at 618 . 
had been born in Russia, none had sought American citizenship, three "frankly avowed" that they were "rebels," "revolutionists," and "anarchists," and the fourth that he was a socialist. ${ }^{58}$ The first two counts of the four count indictment, reminiscent in tone of the Alien and Sedition Acts of a century past, ${ }^{59}$ alleged conspiracies to utter "disloyal, scurrilous and abusive language" concerning the form of government of the United States and to utter language "intended to bring the form of Government of the United States into contempt, scorn, contumely, and disrepute." ${ }^{\prime 60}$ The last two counts were somewhat more restrained, but still broadly drawn: again each charged a conspiracy, the third "to incite, provoke and encourage resistance to the United States" in the war, and the fourth to "urge, incite and advocate curtailment of production of things and products ... essential to prosecution of the war." ${ }^{\prime 1}$ The defendants' first amendment claims were summarily dismissed with a reference to Schenck and Frohwerk. ${ }^{62} \mathrm{~A}$ review of the circulars led the Court to the conclusion that the defendants' intent was domestic revolution and frustration of the war effort, enough to warrant a finding of guilt on the third and fourth conspiracy counts; the other charges were not considered, as sentencing had been concurrent. Following Holmes' lead in the prior cases, the Court deduced the necessary intent from the nature of the language used in the publications and its likely effect. This was consistent with the common law conception that "Men must be held to have intended, and to be accountable for, the effects their acts were likely to produce." $"$ es

Holmes, joined by Brandeis, rebelled and filed a dissent longer than his majority opinions in Schenck, Frohwerk or Debs. Though he stood by the propriety of the convictions in those cases, ${ }^{64}$ he made no attempt to distinguish them on the facts or law. Instead, he now found a need to construe intent in the strictest kind of terms. No longer sufficient for him was the majority's (and seemingly his own earlier ${ }^{65}$ ) broad common law conception of intent. It would not do to infer a generalized kind of purpose from the words themselves; the substan-

58 Id. at 617-18.

59 Act of July 14, 1798, ch. 74, \& 2, 1 Stat. 596.

60250 U.S. at 617.

61 Id.

$621 d$. at 619.

63 Id. at 621.

64 "I never have seen any reason to doubt that the questions of law that alone were before this Court in the cases of Schenck, Frohwerk, and Debs, were rightly decided." Id. at 627 (citations omitted).

65 See text accompanying note 50 supra. 
tive evil-here, interference with the war effort, etc.-must be shown to have been the exact aim of the defendants' actions. ${ }^{66}$ Only when such intent existed, perhaps either alone or with a "present danger of immediate evil" was government warranted in interfering with speech. The puny risk posed by the defendant was relevant, if not crucial: "Now nobody can suppose that the surreptitious publishing of a silly leaflet by an unknown man, without more, would present any immediate danger that its opinions would hinder the success of the government arms or have any appreciable tendency to do so." ${ }^{\text {"67 }}$ The dissent still seemed somewhat unsure, however, about the role of intent; for Holmes added that once given specific intent to obstruct, there might be a greater risk and prosecution might be warranted even without a clear showing of imminent danger. ${ }^{68}$ Even if incorrect with respect to requisite intent and the need for imminency of harm, Holmes thought the sentences of twenty years imposed by the trial court much too severe and only "the most nominal punishment" appropriate, "unless the defendants are to be made to suffer not for what the indictment alleges but for the creed they avow . . ..."

In two subsequent Espionage Act $\operatorname{cases}^{70}$ the majority continued

66 There was no longer room for ambiguity as to what Holmes considered the requirement to be under the Act:

But to make the conduct criminal that statute requires that it should be

"with intent by such curtailment to cripple or hinder the United States in the prosecution of the war." It seems to me that no such intent is proved.

I am aware of course that the word intent as vaguely used in ordinary legal discussion means no more than knowledge at the time of the act that the consequences said to be intended will ensue. Even less than that will satisfy the general principle of civil and criminal liability. A man may have to pay damages, may be sent to prison, at common law might be hanged, if at the time of his act he knew facts from which common experience showed that the consequences would follow, whether he individually could foresee them or not. But, when words are used exactly, a deed is not done with intent to produce a consequence unless that consequence is the aim of the deed. It may be obvious, and obvious to the actor, that the consequence will follow and he may be liable for it even if he regrets it, but he does not do the act with intent to produce it unless the aim to produce it is the proximate motive of the specific act, although there may be some deeper motive behind.

It seems to me that this statute must be taken to use its words in a strict and accurate sense. They would be absurd in any other.

250 U.S. at $626-27$.

$67 \mathrm{Id}$. at 628 .

$48 \mathrm{Id}$.

69 Id. at 629. Decided the same day as Abrams, Stilson v. United States, 250 U.S. 583 (1919), affirmed another conspiracy conviction under the Espionage Act, this time involving publication of a Lithuanian language newspaper. Following the earlier pattern, the danger created by the publication was read solely from its text, with no reference to any of the surrounding circumstances, the breadth or nature of the circulation, or the intended or actual audience, much less the actual or probable reaction evoked in the readers.

70 Schaefer v. United States, 251 U.S. 466 (1920) (conviction based on publication of articles); Pierce v. United States, 252 U.S. 239 (1920) (conviction based on houseto-house distribution of pamphlets). 
to find little need to go beyond an examination of the text of the challenged speech or pamphlet, while dissenters Holmes and Brandeis ${ }^{71}$ insisted that the Court must examine the surrounding circumstances to find evil intent and the requisite danger that harm will occur. In Pierce v. United States, ${ }^{72}$ where Brandeis had tried to join issue on the question of danger and made reference to the actual circumstances of distribution, the majority refused to respond in terms, resting on its general declaration that the matter was for the jury to determine. Except for its somewhat vague reference to the relevance of the time, place and manner of distribution, the majority seemed still to suggest it sufficient for conviction to show concerted action by the defendants, the nature of the document, and defendants' knowledge of its contents.

The final chapter of the World War I Espionage Act conspiracy cases in the Supreme Court was written with the brief opinion in $O^{\prime}$ Connell $v$. United States, ${ }^{73}$ which affirmed convictions for conspiracy to violate the 1917 Act and to violate the Selective Service Law. No details of the defendants' action were given, the opinion was directed mainly to procedural issues, and affirmance rested on citations of Goldman, Schenck and Frohwerk. ${ }^{74}$

71 Justice Clarke joined the dissenters in Schaefer. He asserted various errors in the lower court proceedings which he attributed to the "stress and strain of feeling prevailing in the early months of the late deplorable war." 251 U.S. at 501.

72252 U.S. 239 (1920).

73253 U.S. 142 (1920).

$74 \mathrm{~A}$ concluding footnote to the series of 1918-1920 cases was written a quarter of a century later in Hartzel v. United States, 322 U.S. 680 (1944), a World War II case in which the Court reviewed a conviction under the speech-restricting provisions of $\$ 3$ of the Espionage Act of 1917. The judgment was reversed, 5-4, but there was no opinion of the Court. The defendant Hartzel had been found guilty on all counts of a seven count indictment alleging publication and circulation of three anti-semitic pamphlets depicting the war as a betrayal of America and urging its conversion into a racial conflict, all with intent to cause insubordination and disloyalty in the armed forces and to obstruct recruiting and enlistment services. The documents had been mailed anonymously to various public figures, including some military officials. Reversal of a finding of guilt on a conspiracy count was required, according to the plurality opinion, because the convictions of the only two co-conspirators named in the indictment had already been set aside by the courts below. Justice Murphy, writing for only four members of the Court, including himself, then went on to declare that the government must prove, beyond a reasonable doubt, both an "objective" and a "subjective" element of the crime: the first, that defendant's conduct created a "clear and present danger" and the second, that he specifically intended interference with the armed forces or with recruitment. 322 U.S. at 686-87. The requisite specific intent, which Murphy found not in constitutional imperatives, but in the statute's use of the word "willfully," could be "proved not only by the language actually used in the statements or writings themselves but also by the circumstances surrounding their preparation and dissemination." Id. at 687. Upon a review of the evidence, Murphy concluded that the government had failed to carry its burden on intent and thus the convictions on the remaining six substantive counts must also be reversed. Justice Roberts concurred separately in a twosentence note which did no more than mark his agreement that the evidence was insufficient to take the case to the jury, thus creating a majority for the result. Justices Reed, Frankfurter, Douglas (Douglas!), and Jackson dissented. 


\section{The Communist Party Cases}

The 1950's and early 1960's witnessed another round of conspiracy cases in the political arena. Played against the background of the Cold War to a public moved by anti-communist fear and suspicion, these later decisions have much in common with the World War I cases. The tone of the post-World War II opinions was different-they were more sophisticated and, as compelled by the intervening development of first amendment doctrine, they asserted a serious concern for speech rights. Although evolution of the free speech law had laid the foundation for an emerging, if inadequate, recognition of the doctrinal and policy conflict engendered by utilization of conspiracy in the speech area, the period saw a nonetheless renewed pattern of largely uncritical judicial affirmances of convictions for conspiracy to advocate, and, finally, even for membership in the Communist Party.

\section{A. Dennis}

Dennis v. United States, ${ }^{75}$ the landmark case sustaining the constitutionality of the Smith Act, ${ }^{76}$ both on its face and as applied to a group of Communist Party leaders, displayed a variety of approaches to the speech-conspiracy problem; little of it, however, was authoritative. A divided Court affirmed convictions for conspiracy to teach and advocate violent overthrow of the government and to organize the Communist Party for teaching and advocacy to the same purpose. The five opinions in the case ran nearly one hundred pages, but there was none on which a majority of the eight-man Court could agree. Chief Justice Vinson, writing for himself and three other Justices, ${ }^{77}$ viewed the major issues in the case as, first, whether the clear and present danger test developed in the World War I decisions applied in the case of a statute like the Smith Act which expressly proscribed certain kinds

75341 U.S 494 (1951).

76 Smith Act, ch. 439, 54 Stat. 670 (1940), as amended, 18 U.S.C. \& 2385 (Supp. 1972). Title I, $\S \S 2,3$ provide:

Sec. 2. (a) It shall be unlawful for any person-(1) to knowingly or willfully advocate, abet, advise, or teach the duty, necessity, desirability, or propriety of overthrowing or destroying any government in the United States by force or violence, or by the assassination of any officer of any such government. ...

(3) to organize or help any society, group, or assembly of persons who teach, advocate, or encourage the overthrow or destruction of any government in the United States by force or violence; or to be or become a member of, or affiliate with, any such society, group, or assembly of persons, knowing the purposes thereof.

Sec. 3. It shall be unlawful for any person to attempt to commit, or to conspire to commit, any of the acts prohibited by the provisions of this title.

77 Chief Justice Vinson announced the judgment of the Court and authored the plurality opinion in which Justices Reed, Burton, and Minton joined. Justices Frankfurter and Jackson each filed separate concurrences. Justices Black and Douglas dissented. 
of speech, and, second, if it did, what its real meaning was. After reviewing the 1917 Espionage Act opinions (with nary a notice of the fact that they too involved indictments for conspiracy), the Chief Justice concluded that Holmes and Brandeis were correct not only in that series of cases, but also in their later dissent in Gitlow v. New York, ${ }^{78}$ where they contended that the clear and present danger test must always be applied even under a criminal statute directly aimed at speech. ${ }^{70}$

Not surprisingly, Vinson found prevention of revolution a suffciently substantial governmental interest to warrant suppression of speech (so stated, how could the conclusion be otherwise?), ${ }^{80}$ and determined that the probable success or failure of the conspiracy could not be the relevant criterion for evaluating danger. Adopting Learned Hand's modification of the Schenck test in the court below, ${ }^{81}$ the opinion moved quickly to the conclusion that the constitutional requisites had been met. The conspirators' high degree of organization and rigid discipline, together with "the inflammable nature of world conditions, similar uprisings in other countries, and the touch-and-go nature of our relations with countries with whom petitioners were in the very least ideologically attuned" combined to meet the requirements of the redefined clear and present danger test. ${ }^{82}$

The next three sentences-the only ones in Vinson's opinion even directed to the point-dealt with the fact that it was a conspiracy case being decided: "And this analysis disposes of the contention that a conspiracy to advocate, as distinguished from the advocacy itself, cannot be constitutionally restrained .... . It is the existence of the conspiracy which creates the danger. If the ingredients of the reaction are present, we cannot bind the Government to wait until the catalyst is

78268 U.S. 652,672 (1925).

79 See also the Brandeis-Holmes concurring opinion in Whitney v. California, 274 U.S. 357, 372 (1927). Vinson commented: "Although no case subsequent to Whitney and Gitlow has expressly overruled the majority opinions in those cases, there is little doubt that subsequent opinions have inclined toward the Holmes-Brandeis rationale." 341 U.S. at 507. Although he did not share the position taken by Holmes and Brandeis, Frankfurter noted in his own concurrence, that "it would be disingenuous to deny that the dissent in Gitlow had been treated with the respect usually accorded to a decision." Id. at 541. Whitney was finally expressly overruled in Brandenburg v. Ohio, 395 U.S. 444 (1969).

80 Justice Black, a vigorous opponent of this so-called "balancing test" which would weigh the government interest in abridgment against the interest in speech, saw the "doctrine [as] . . . capable of being used to justify almost any action Government may wish to take to suppress First Amendment freedoms." Scales v. United States, 367 U.S. 203, 259, 262 (1961) (dissenting opinion).

81 In each case [courts] must ask whether the gravity of the "evil," discounted by its improbability, justifies such invasion of free speech as is necessary to avoid the danger.

United States v. Dennis, 183 F.2d 201, 212 (2d Cir. 1950).

82341 U.S. at 511. 
added. ${ }^{283}$ Strangely enough, except for Goldman v. United States, ${ }^{84}$ the authorities relied upon were two non-speech criminal conspiracy cases rather than any of the later series of World War I Espionage Act cases of which Vinson's brief reasoning was so reminiscent. ${ }^{85}$ The opinion contained no substantive analysis of the elements of the crime and nothing significant was said about intent, except to note in general terms that it was required. There was no review of the evidence, although the grant of certiorari went to the constitutionality of the Smith Act as applied..$^{86}$

Justice Frankfurter's lengthy concurring opinion did not discuss the conspiracy question as such; it was devoted mainly to exposition of his view that, given the Smith Act's explicit prohibitions on speech, the question was not whether defendants' actions presented a clear and present danger (a standard he viewed as unsatisfactory in any event), but whether the legislature's statutory resolution of the conflict between free speech and national security was a reasonable one. He concluded that the congressional balancing embodied in the Smith Act was within "the pale of fair judgment"87 and that the Act, whether wise or unwise, was therefore constitutional.

The three remaining opinions, Justice Jackson's in concurrence, and Justice Black's and Justice Douglas' in dissent, accorded specialand contradictory-significance to the fact that the defendants had been charged with conspiracy.

The dissents took objection to the very application of conspiracy to speech crimes. Justice Black was in "basic disagreement" with the Court and asserted his "fundamental difference in constitutional approach." throw the Government. . . . They were not even charged with saying anything or writing anything designed to overthrow the Government. The charge was that they agreed to assemble and to talk and publish certain ideas at a later date ... to use speech ... in the future to teach and advocate the forcible overthrow of the Government."89 To Black this was "a virulent form of prior censorship" forbidden by the first

83 Id. (citations omitted).

84245 U.S. 474 (1918); see text accompanying notes 68-74 supra.

85 In addition to Goldman, the Court cited only Pinkerton v. United States, 328 U.S. 640 (1946), and United States v. Rabinowich, 238 U.S. 78 (1915). The former involved a conspiracy to violate federal tax laws and the latter a conspiracy to violate provisions of the Bankruptcy Act. Interestingly, Rabinowich was the only conspiracy case cited in Goldman. See note 44 supra.

86340 U.S. 863 (1950).

87341 U.S. at 540 .

$88 I d$. at 579.

$89 \mathrm{Id}$. 
amendment; to the extent the Smith Act authorized such a prosecution, it was unconstitutional, as presumably would be all attempts to punish conspiracies to commit crimes of speech. Even on the "radical assumption" that the defendants could be punished "for the crime of actual advocacy," although not indicted for it, affirmance would repudiate the clear and present danger rule and "greatly restrict" first amendment protections. ${ }^{90}$

As unhappy as it might be to make speech itself a crime, the added fillip of conspiracy made it only more offensive to Justice Douglas:

The vice of treating speech as the equivalent of overt acts of a treasonable or seditious character is emphasized by a concurring opinion, which by invoking the law of conspiracy makes speech do service for deeds which are dangerous to society. The doctrine of conspiracy has served divers and oppressive purposes and in its broad reach can be made to do great evil. But never until today has anyone seriously thought that the ancient law of conspiracy could constitutionally be used to turn speech into seditious conduct. Yet that is precisely what is suggested. I repeat that we deal here with speech alone, not with speech plus acts of sabotage or unlawful conduct. Not a single seditious act is charged in the indictment. To make a lawful speech unlawful because two men conceive it is to raise the law of conspiracy to appalling proportions. That course is to make a radical break with the past and to violate one of the cardinal principles of our constitutional scheme. ${ }^{91}$

For present purposes, Justice Jackson's concurrence was perhaps the most interesting opinion in Dennis. The initial question for Jackson was whether the clear and present danger test should be applied to the case before the Court. He concluded that it should not, but for reasons wholly different from those of Frankfurter. His view was that the doctrine had been devised for other purposes in an earlier era, and had simply been outrun by the recent development of more sophisticated revolutionary techniques. ${ }^{22} \mathrm{He}$ cited particularly the Communist

90 Id. at 579-80.

91 Id. at 584 .

92 Jackson did not urge that the clear and present danger test be discarded altogether. He would 'save it, unmodified, for application as a 'rule of reason' in the kind of case for which it was devised":

When the issue is criminality of a hot-headed speech on a street corner, or circulation of a few incendiary pamphlets, or parading by some zealots behind a red flag, or refusal of a handful of school children to salute our flag, it is not beyond the capacity of the judicial process to gather, comprehend, and weigh the necessary materials for decision whether it is a clear and present danger of substantive evil or a harmless letting off of steam. It is not a prophecy, for the danger in such cases has matured by the time of trial or it was never present. The test applies and has meaning where a conviction is sought to be based on a speech or writing which does not directly or explicitly advocate a crime but 
Party's reliance on a secret, tightly disciplined organization, infiltration of government and private groups, use of subtle propaganda, and the like, none of which, he thought, were effectively subject to control or limit by the more traditional legal methods utilized against anarchists, pacifists, socialists, and other, simpler radicals of the World War I period and shortly thereafter.$^{93}$ Though he would not sanction use of the Holmes-Brandeis test, his reasons-ironically enoughseemed to go to the very danger he perceived in the increased "subtlety and efficacy of modernized revolutionary techniques used by totalitarian parties," "94 here obviously Communists. The distinction, then, came down to several possibilities: that, in Jackson's view, the Communist Party constituted an especially clear and present danger, an intriguingly tautological approach; or that it, as a group, was to be treated as sui generis; or that, as he went on to suggest more clearly, there was simply no need to appraise the risk in a speech case when the charge was conspiracy, thereby conveniently ignoring the fact that the clear and present danger doctrine was itself developed in a series of conspiracy cases. ${ }^{95}$

Jackson had no doubt whatsoever about what kind of case it was or the sources that should be looked to for resolution of the issues:

What really is under review here is a conviction of con-

to which such tendency is sought to be attributed by construction or by implication from external circumstances.

Id. at 568.

93 The problem was then, for Jackson, that "either by accident or design, the Communist stratagem outwits the anti-anarchist pattern of statute aimed against 'overthrow by force and violence' if qualified by the doctrine that only 'clear and present danger' of accomplishing that result will sustain the prosecution." Id. at 567. Support for the Jackson position can be found in O. KIRChHETMER, Political JUSTICE 140 (1961), where in discussing Dennis, the author declares the clear and present danger test to be "obsolete," at least with respect to "Communist . . . activity." For a more lengthy exposition of Justice Jackson's view of the danger and evils of the Communist party, see his concurring opinion in American Communication Ass'n v. Douds, 339 U.S. 382, 424-33 (1950).

94341 U.S. at 567.

95 To support his rejection of the clear and present danger test, Jackson drew upon non-speech conspiracy law, quoting from cases in the anti-trust area:

In conspiracy cases the Court not only bas dispensed with proof of clear and present danger but even of power to create a danger: "It long has been settled, however, that a 'conspiracy to commit a crime is a different offense from the crime that is the object of the conspiracy? . . . Petitioners, for example, might have been convicted here of a conspiracy to monopolize without ever having acquired the power to carry out the object of the conspiracy. ..."

Having held that a conspiracy alone is a crime and its consummation is another, it would be weird legal reasoning to hold that Congress could punish the one only if there was "clear and present danger" of the second. This would compel the Government to prove two crimes in order to convict for one.

341 U.S. at 576-77. Jackson seems quite wrong about the need to prove "two crimes." Showing the existence of a "clear and present danger" of consummation is obviously not the same as proving consummation. Beyond his familiar exposition of the rationale of conspiracy, Jackson gave no reason for affording lesser protection to an agreement to speak than to speech itself. 
spiracy, after a trial for conspiracy, on an indictment charging conspiracy, brought under a statute outlawing conspiracy. With due respect to my colleagues, they seem to me to discuss anything under the sun except the law of conspiracy. One of the dissenting opinions even appears to chide me for "invoking the law of conspiracy." As that is the case before us, it may be more amazing that its reversal can be proposed without even considering the law of conspiracy..$^{96}$

With the clear and present danger test out of the way, and the remaining questions focused mainly in terms of conspiracy law, the result readily followed; the assumptions underlying Jackson's application of the conspiracy concepts to the speech area are worth setting out:

The Constitution does not make conspiracy a civil right. The Court has never before done so and I think it should not do so now. Conspiracies of labor unions, trade associations, and news agencies have been condemned, although accomplished, evidenced and carried out, like the conspiracy here, chiefly by letter-writing, meetings, speeches and organization. Indeed, this Court seems, particularly in cases where the conspiracy has economic ends, to be applying its doctrines with increasing severity. While I consider criminal conspiracy a dragnet device capable of perversion into an instrument of injustice in the hands of a partisan or complacent judiciary, it has an established place in our system of law, and no reason appears for applying it only to concerted action claimed to disturb interstate commerce and withholding it from those claimed to undermine our whole Government. ${ }^{97}$

What is striking in Jackson's analysis is the failure to recognize a distinction between conspiracy prosecutions in which the overt acts are speeches or writings but where the combination has non-speech objectives, and Dennis itself, in which the object of the alleged conspiracy was speech. He followed traditional reasoning about the increased danger flowing from the existence of a combination whose purpose is to effect unlawful ends and moved easily over the constitutional problem raised by the fact that the ends, being speech, are presumptively protected:

I do not suggest that Congress could punish conspiracy to advocate something, the doing of which it may not punish.... But it is not forbidden to put down force or violence, it is not forbidden to punish its teaching or advocacy, and the end 
being punishable, there is no doubt of the power to punish conspiracy for the purpose..$^{98}$

It is ironic that Jackson should have relied so heavily. on the common law conceptions of conspiracy and rejected the palpable relevancy of the free speech line of cases. He, after all, had only two years earlier authored the famous concurring opinion in Krulewitch v. United States, ${ }^{99}$ vigorously criticizing the evils and misuse of conspiracy doctrine.

While not accepted by the Court, Jackson's analysis is nonetheless significant-in part, because it illustrates the dangers of even a more benign and somewhat less strict adaptation of conspiracy doctrine to the speech area: to the extent that the conspiracy aspect of the case is emphasized, the element of speech protection is almost inevitably diminished. Moreover, apart from his rejection of the clear and present danger test, Jackson articulated in honest detail the premises implicit in the plurality opinion.

Justice Jackson was apparently troubled by the inchoate nature of conspiracy. ${ }^{100}$ It was possible, and perhaps even proper and useful, to apply the clear and present danger test in the case of a "hot-headed speech on a street corner," or in one involving "circulation of a few incendiary pamphlets," because it was "not beyond the capacity of the judicial process to gather, comprehend, and weigh the necessary materials for decision whether it is a clear and present danger of substantive evil or a harmless letting off of steam."101 In such instances the effect of the speech can be judged because it has already occurred. ${ }^{102}$ As Jackson noted, "the danger in such cases has matured by the time of trial or it was never present." ${ }^{1103}$ But when the crime is charged in order to thwart future consequences, i.e., employed to prosecute a still unexecuted conspiracy, as Jackson apparently viewed Dennis to be, then the attempt to measure the danger posed by the combination is predictive; it is, as Jackson would have it, a "prophecy." 104 This recognition led Jackson not to retreat from the application

98 Id. at 575 .

99336 U.S. 440,445 (1949). Krulewitch was a prosecution for conspiracy to violate the Mann Act.

100 Justice Black evidenced a similar awareness, of course, by his categorization of the case as one involving "prior censorship." 341 U.S. at 579.

101 Id. at 568. See also note 92 supra.

102 When that is true, of course, it is possible to allege actual incitement or advocacy, itself, and there is no reason to rely on the conspiracy charge, either alone or in a companion count. Jackson's earlier concurring opinion in Kruleweritch, 336 U.S. 440, 445 (1949), specifically condemned unwarranted prosecutorial reliance on conspiracy when a substantive charge alone would do.

103341 U.S. at 568.

$104 I d$. 
of criminal sanctions in Dennis, but rather to reject the clear and present danger test altogether. To be sure, he did speak of the particular dangers of the Communist Party, as he appraised them, but this was not part of any attempt to measure the constitutional propriety of punishment in the particular case (the purpose of the clear and present danger doctrine). He was seeking to demonstrate the impropriety of using the Holmes-Brandeis test, or any like it. Thus, Jackson recognized the tension between the concept of conspiracy as an inchoate crime and any test focusing upon the immediacy of danger, but moved from this awareness not to greater protection for first amendment rights but instead to strict application of restrictive conspiracy doctrine.

Jackson reached the same result as did Chief Justice Vinson for the plurality, but by a very different process of reasoning. Vinson showed no conscious appreciation of the difficulty presented by the treatment of conspiracy as an inchoate offense. He proceeded to apply the test and measure the "danger," apparently drawing for his appraisal upon judicially noticed "facts" and his own seemingly dispositive predeliction toward weighing the risk of domestic communism heavily.

The choice between Vinson and Jackson presents something of a dilemma. If Justice Jackson's view as to the limited uses of the clear and present danger test is to prevail, we are led to the imposition of criminal sanctions for the planning of speech, which if actually uttered might not itself be constitutionally punishable. ${ }^{105}$ On the other hand, to follow Vinson and apply the clear and present danger test in speechconspiracy cases may accomplish but little; it may do no more than leave the door open to what Jackson properly characterizes as prophetic judgments as to the impact of speech, judgments too often exemplified by the kind of analysis, or lack of it, found in the World War I Espionage Act cases and, indeed, in Dennis itself, judgments that have no anchor in reliable forms of proof and are highly susceptible to distortions born of popular fear and passion.

The very ease with which the plurality in Dennis could invoke the threat of international communism and relate the case before the Court to world conditions illustrates a subtle but important consequence of the use of conspiracy. Applied to speech, it reinforces the tendency

105 This could be so if the speech failed to meet the requisite test, be it "clear and present danger" either as stated by Holmes and Brandeis or as reformulated in Dennis, or as suggested more recently by the Court in Brandenburg v. Ohio, 395 U.S. 444, 447 (1969) ("likely to incite or produce" imminent lawless action). It should be noted, of course, that the Jackson rejection of the "clear and present danger" test (and presumably of its variants as well) in a conspiracy case would give the prosecution a ready means to avoid application of a potential impediment to conviction simply by varying the charge from that of incitement or advocacy, to conspiracy to incite or advocate, i.e., the Dennis formula. 
toward an escalated evaluation of the perceived risk. Once the conspiracy element is added-even where the speech has already occurred-it becomes fairly simple for judges (or juries) to forget that it is still speech being dealt with, not some mystical criminal combination. The charge in Dennis was not a conspiracy to engage in revolution, it was conspiracy to engage in speech, albeit its ultimate purpose may or may not have been revolution. The distinction can readily turn out to be elusive. In a later Communist Party case the Court described Dennis as involving an "agreement to accomplish overthrow."106 In Dennis itself, the Vinson and Jackson opinions focused less on what the defendants before the Court actually said than on the asserted enormity of the danger posed by their ideology and their movement. Where the charge is incitement, the Court must recognize that the defendant's words are crucial to his criminality; with conspiracy there is a shift in emphasis. Unlike the World War I cases, it appears in Dennis that the measure of danger and its imminence were not tested by the words of the several defendants, but by the vaguely described threat of the communist conspiracy-domestic and global. Once the standard is applied to the group and its shrouded purposes, not to the speech itself, the way is opened to the most broadly based kind of judgment, freed from whatever restraint there may be in linking the appraisal of danger to the specific words of a specific defendant. The increased opportunity for play of judicial predisposition is obvious. ${ }^{107}$

Deference to first amendment interests and sensitivity to the concerns which motivate treatment of speech rights as enjoying some "preferred position" would strongly suggest the need for particular examination of the reality of the danger posed by any specific speechconspiracy, rather than (as Jackson in Dennis suggests) wholesale and uncritical acceptance of the mythology of group danger surrounding conspiracy. The conjunction of speech and conspiracy tends toward too ready a dilution of constitutional protections, both in conceptual and pragmatic terms.

\section{B. Yates}

If Dennis exhibited a friendliness to the adoption, in speech-conspiracy cases, of the traditional doctrine that the fact of agreement is

108 Yates v. United States, 354 U.S. 298, 324 (1957); see text accompanying note 108 infra.

$107 \mathrm{O}$. KRRCHAEIMER, supra note 93 , at 148, makes a similar point with respect to Yates v. United States, 354 U.S. 298 (1957), which is discussed at text accompanying notes 108-16 infra:

The Yates case shows how the potentiality of a revolutionary party can be evaluated differently, according to whether its general mold and structure are taken into account or whether judgment is based on evidence of specific action. 
itself enough for illegality, regardless of whether the conspiracy has matured to the point of implementation, one of the later Communist Party cases took some pains to limit the breadth of the implications which could be drawn from the opinions of Chief Justice Vinson and Justice Jackson. But the circumscription of Dennis had to wait six years-until the paranoia and hysteria of the McCarthy era had abated and until the accession of a new Chief Justice and a differently constituted Court. Writing for a four man majority in Yates v. United States, ${ }^{108}$ reversing Smith Act conspiracy convictons, ${ }^{109}$ Justice Harlan noted a possible distinction between an executed and an executory speech-conspiracy and expressly negatived the suggestion that the Court in Dennis had spoken to the constitutional permissibility of punishing a conspiracy to engage in future speech. He was first careful to classify Dennis and prior Smith Act cases as ones which "involved advocacy which had already taken place, and not advocacy still to occur."110 Dennis' rejection of the argument "that a conspiracy to advocate, as distinguished from the advocacy itself, cannot be constitutionally restrained, because it comprises only the preparation," and its declaration that "it is the existence of the conspiracy which creates the danger,"111 had to be taken (according to Harlan) to refer to "more than the basic agreement to advocate."112 Indeed, in his attempt to restrict Vinson's language, Harlan made it sound as if the charge in Dennis had been conspiracy to overthrow and not conspiracy to advocate overthrow:

The reference of the term "conspiracy," in context, was to an agreement to accomplish overthrow at some future time, implicit in the jury's findings under the instructions given, rather than to an agreement to speak. Dennis was thus not concerned with a conspiracy to engage at some future time in seditious advocacy, but rather with a conspiracy to advocate presently the taking of forcible action in the future. It was action, not advocacy, that was to be postponed until "cir-

108354 U.S. 298 (1957).

100 The defendants were charged, under the Act, with having conspired to advocate and teach overthrow and to organize the Communist Party for the same purposes. The convictions were reversed because of errors in the instructions to the jury and the case remanded, but with a direction that acquittals be entered for five of the fourteen defendants because, as to them, the evidence was "palpably insufficient" to show either the requisite specific intent or their membership in the conspiracy charged. The Government never retried the other nine. For a recounting of the subsequent history of prosecutions under the Act, see W. GELLHORN, AMERICAN RIGHTS 82 (1960) and Mollan, Smith Act Prosecutions: The Effect of the Dennis and Yates Decisions, 26 U. PIrT. L. Rev. 705 (1965).

110354 U.S. at 323.

111341 U.S. at 511.

112354 U.S. at 323. 
cumstances" would "permit." We intimate no views as to whether a conspiracy to engage in advocacy in the future, where speech would thus be separated from action by one further remove, is punishable under the Smith Act. ${ }^{113}$

Although Harlan's suggestion of a distinction between a prosecution for a conspiracy to advocate in which the advocacy had already occurred, and one in which the advocacy had yet to take place, ${ }^{114}$ was framed in terms of possible statutory construction, rather than as a matter of constitutional compulsion, he was probably mindful of the additional difficulties of sustaining under the first amendment a conviction for conspiracy based on words not yet spoken. Indeed, the very need for a line between the two types of situations-present and future advocacy-was sharpened by yet another aspect of Yates. One ground for reversal of the convictions in Yates was that the instructions of the trial court did not sufficiently articulate for the jury the difference between mere advocacy of doctrine, which was legal, even if done with evil motive, and advocacy of action, which if coupled with the requisite intent, was fully punishable. While this holding was also couched in terms of the intended reach of the Smith Act, ${ }^{115}$ its constitutional resonance was unmistakable. Any doubt that the point was based on the first amendment was subsequently dispelled by Brandenburg v. Ohio. ${ }^{116}$

Yates' insistence that there be "urging of action" (that the listeners be urged to "do something ... rather than merely to believe in something"), ${ }^{117}$ or use of the "language of incitement"118 or language which has a "tendency to generate action"119 would seem to make the

113 Id. at 324. But in Noto v. United States, 367 U.S. 290 (1961), decided four years later, Harlan, as spokesman for the Court, suggested that even a conspiracy to engage in future advocacy might be punishable under the Act. See text accompanying note 127 infra.

114 To be sure, Harlan may have been attempting to distinguish between an unexecuted conspiracy to advocate, with the actual advocacy imminent, and one to advocate at some indefinite time in the future, rather than to draw a line between cases in which the advocacy had already occurred and one which it had not, even if immediately impending. The latter distinction seems both more tenable and more likely, not only in terms of probable constitutional dimension, but because of Harlan's insistence only a few sentences earlier on the fact that Dennis and the earlier Smith Act cases involved already-accomplished advocacy.

115 See 354 U.S. at $318-19$.

110395 U.S. 444 (1969). Brandenburg held unconstitutional an Ohio Criminal Syndicalism statute on the express ground that it failed to distinguish between advocacy of action and of doctrine, the distinction enunciated in Yates.

117354 U.S. at 325.

118 Id. at 321 (quoting Dennis).

119 Id. at 320 . Four years later, in Scales v. United States, 367 U.S. 203 (1961), sustaining a conviction under the "membership" clause of the Smith Act, Justice Harlan, again writing for the Court, described the Yates standard as requiring that the advocacy be "uttered in terms reasonably calculated to "incite' to such overthrow." 367 U.S. at 230 . 
precise phrasing of the defendant's speech crucial to any determination of criminality. Without such a focus, indeed perhaps without scrutiny of the exact words, one cannot possibly determine whether or not the exhortations fit the Yates description. While one could, of course, argue that the issue in the conspiracy context is not the language actually used, but the words which the defendants intended to use (an elusive inquiry at best) this seems patently inconsistent with Yates' effort to assure careful delineation of the proscribable area of speech and its explicit and emphatic rejection of the lower court's view which would have had evil motive do the work of "words of action" by allowing conviction for otherwise permissible advocacy so long as coupled with specific intent to accomplish overthrow. Moreover, it ignores the very real possibility that the defendant would never have actually spoken the words he is charged with intending. Perhaps most importantly, it augments intrusion upon the constitutionally protected area of speech. Unless one is willing to give controlling significance to the well-worn dogma about the measurably increased dangers of combination, it is difficult to understand why-as Justice Jackson would have had it in Dennis - an agreement to make a speech which exists only in the defendants' minds is entitled to less protection than a speech which has actually been delivered.

\section{Membership Cases}

In Scales v. United States ${ }^{120}$ and Noto v. United States, ${ }^{121}$ both decided the same day, the Court had occasion to consider the constitutionality and application of the "membership" clause of the Smith Act which in terms made it a crime to become "a member" of "any society, group, or assembly of persons who teach, advocate, or encourage the overthrow or destruction" of the government by force and violence, "knowing the purposes thereof."122 In opinions again written by Justice Harlan, the Court sustained the conviction of Scales but, on evidentiary grounds, reversed that of Noto. The decisions are significant because of the close analogy between criminal conspiracy and the proscription of membership in an organization because of its assertedly illegal objectives. The Court recognized the parallel and nodded to the obviously heightened constitutional obstacles inhering in the fact that the organization affected was one purporting to be a political party, a factor equally present but left unremarked in Dennis. Still, Harlan had no great difficulty in sustaining the validity of the membership 
clause. First, the Court imputed to the statute a requirement that the proscribed membership be more than passive; in addition to knowing of the organization's illegal activities, and specifically intending to further them, the defendant must have been an "active" participant in the affairs of the group. This limitation was watered down, however, by the notation that it was enough to prove such activity in connection with "general Party affairs," not necessarily the specifically illegal activities. ${ }^{123}$

These prerequisites to conviction-knowledge, specific intent, and active membership-were taken to be enough, in combination, to defeat not only the first amendment claim of Scales, ${ }^{124}$ but his argument that membership was an insufficiently substantial relationship to meet fifth amendment-due process concepts of "personal guilt." Justice Harlan cited "familiar concepts of the law of conspiracy and complicity" to dispel the "thought that due process puts beyond the reach of the criminal law all individual associational relationships, unless accompanied by the commission of specific acts of criminality."125

123 See 367 U.S. at 223 n.15:

The element of "activity" in the proscribed membership stands apart from the ingredient of guilty "knowledge" in that the former may be shown by a defendant's participation in general Party affairs, whereas the latter requires linking him with the organization's illegal activities.

124 Because Dennis had held that advocacy of the type in question was not protected and that "combination [conspiracy] to promote such advocacy, albeit under the aegis of what purports to be a political party," was punishable, 367 U.S. at 228-29, what followed in Scales required no great advance in reasoning. It seemed almost a foregone conclusion that the Court would "discern no reason why membership, when it constitutes a purposeful form of complicity in a group engaging in the same forbidden advocacy, should receive any greater degree of protection from the guarantees of that Amendment." Id. at 229. The potential chill on exercise of speech rights by virtue of threatened prosecutions under the statute was seen as limited or non-existent because of the knowledge and specific intent requirements:

If it is said that the mere existence of such an enactment tends to inhibit the exercise of constitutionally protected rights, in that it engenders an unhealthy fear that one may find himself unwittingly embroiled in criminal liability, the answer surely is that the statute provides that a defendant must be proven to have knowledge of the proscribed advocacy before he may be convicted.... The clause does not make criminal all association with an organization which has been shown to engage in illegal advocacy. There must be clear proof that a defendant "specifically intend[s] to accomplish [the aims of the organization] by resort to violence."

Id. at 229 (footnotes omitted). Scales did not discuss the applicability of the "clear and present danger" test "as both sides appear to agree that [it] ... reaches the membership clause of the Smith Act, and since the petition for certiorari tenders no issue as to the method of applying it ...."Id. at $230 \mathrm{n} .21$.

$125 \mathrm{Id}$. at 225. The imputation of individual guilt on the basis of a defined relationship to other persons or to an organized group could, of course, find general grounding in the law of conspiracy. But there were differences between the case at hand and the usual conspiracy, and Justice Harlan therefore thought it fit to explore somewhat more fully the exactness of the parallel. There was the obvious question of what could actually be read into the fact of membership:

It must indeed be recognized that a person who merely becomes a member of an illegal organization by that "act" alone need be doing nothing more than signifying his assent to its purposes and activities on one hand, and providing, on the other, only the sort of moral encouragement which comes from the 
Noto re-emphasized the need for strict proof of all elements of the membership offense as protection against sweeping innocent sympathizers within the net of criminality. ${ }^{126}$ But the reversal on evidentiary grounds provided but slight counterpoint to the resolution of the larger constitutional issues in Scales. And Harlan included a curious passage in the Court's opinion; it was almost too casual in light of his carefully worded opinion in Yates where he had specifically reserved the question of illegality of a conspiracy to advocate in the future:

... there is no evidence that such acts of sabotage were presently advocated; and it is present advocacy and not an intent to advocate in the future or a conspiracy to advocate in the future ... which is an element of the crime under the membership clause. To permit an inference of present advocacy from evidence showing at best only a purpose or a conspiracy to advocate in the future would be to allow the jury to blur the lines of distinction between the various offenses punishable under the Smith Act. $^{127}$

It is not clear whether this suggestion that a conspiracy to advocate in the future would be punishable under other sections of the Smith Act represents a conscious repudiation of the studied neutrality expressed in Yates.

And thus, with the Scales-Noto ascription of conspiracy-like liability to membership in an organized political group arguably possessed of both legal and illegal aims, the stage was finally set for the legal confrontation with Dr. Spock's more informal group of political actors.

knowledge that others believe in what the organization is doing. It may indeed be argued that such assent and encouragement do fall short of the concrete, practical impetus given to a criminal enterprise which is lent for instance by a commitment on the part of a conspirator to act in furtherance of that enterprise. A member, as distinguished from a conspirator, may indicate his approval of a criminal enterprise by the very fact of his membership without thereby necessarily committing himself to further it by any act or course of conduct whatever. Id. at 227-28. It is difficult to be sure whether, by the time it finished, the Court had made less or more out of "membership" than of conspiracy. In any event, notwithstanding its putative distinctions, the only real difference in conception between traditional conspiracy and illegal membership under the Smith Act-given the latter's requirement of knowledge and specific intent-seemed to be substitution of the element of "active membership" for the usually required "agreement." On a more practical level, it was doubtful whether all the procedural advantages available to the prosecution in a conspiracy case would attach equally under an indictment for membership. And certainly, it was not insignificant that the Act, in terms, and as Harlan read it, required that the illegal advocacy already have occurred. See text accompanying note 127 infra.

126 [The requisite criminal intent] must be judged strictissimi juris, for otherwise there is a danger that one in sympathy with the legitimate aims of such an organization, but not specifically intending to accomplish them by resort to violence, might be punished for his adherence to lawful and constitutionally protected purposes, because of other and unprotected purposes which he does not necessarily share.

367 U.S. at $299-300$.

$127 I d$. at 298-99 (emphasis partially added). 


\section{The Spock CASE}

The government prosecution in United States $v$. Spock ${ }^{128}$ once again presented-this time against the backdrop of the Vietnamese war-the conflict between the government's pursuit of an alleged conspiracy and the claim of indicted defendants to first amendment protection. Dr. Benjamin Spock and three others, ${ }^{129}$ Rev. William Sloane Coffin, Jr., Michael Ferber, and Mitchell Goodman, were convicted under a single count indictment under section 12 of the Military Selective Service Act of $1967 .^{130}$ The charge was that the defendants, along with others, had conspired to "counsel, aid and abet" draft registrants to "evade [military] service ... and all other duties required" of them under the Universal Military Training and Service Act and to "hinder and interfere ... with the administration" $" 131$ of that Act.

The court of appeals set out the salient events upon which the prosecutions were based:

As is well known, the war in Vietnam and the draft to support it have engendered considerable animosity and frustration. In August 1967 a number of academic, clerical, and professional persons discussed the need of more vigorous opposition to governmental policies. From their eventually consolidated efforts came a document entitled "A Call to Resist Illegitimate Authority" (hereinafter the Call) and a cover letter requesting signatures and support. The letter was signed by defendant Dr. Benjamin Spock and defendant Rev. William Sloane Coffin, Jr., and two other persons. The Call was originally signed by them, numerous others, and eventually by hundreds. The defendant Mitchell Goodman had been preparing a somewhat similar statement against the war and the draft. In mid-September he learned of the Call, which he also signed. He, Coffin, Spock and others spoke on October 2 at a press conference in New York City to launch the Call. It was there announced by Goodman that further activities were contemplated, including a nationwide collection of draft cards and a ceremonial surrender thereof to the Attorney General. On October 16 a draft card burning and turn-in took place at the Arlington Street Church in Boston, arranged by the defendant Michael Ferber, and participated in by Coffin. Four days afterwards all four defendants attended a demonstration in Washington, in the course of which an unsuccessful attempt was made to present the fruits of that collection and similar gatherings to the Attorney General. ${ }^{\mathbf{1 3 2}}$

128416 F.2d 165 (1st Cir. 1969).

129 A fifth defendant, Marcus Raskin, was acquitted in the trial court.

13050 U.S.C. App. $\$ 462$ (a) (1970).

131416 F.2d at 168.

132 Id. (footnotes omitted). 
The court reversed all of the convictions because the trial court, in addition to asking for a general verdict, had erred by putting a series of "special questions" to the jury. Finding the evidence insufficient as to two of the defendants (Spock and Ferber), the court ordered their acquittal, but left the way open to retrial of the remaining pair (Goodman and Coffin). Neither side sought further review and the government, for undisclosed reasons of its own, chose not to exercise its option to reprosecute. Thus, the case ended with no clear victor and we are left, as Professor Packer has said, with a decision that was "unsatisfactory (to both sides)."133 The First Circuit opinionsmajority and dissent-are indeed troublesome, though each attempted to grapple seriously with the contending claims.

\section{A. The Majority's "Safeguards"}

The Spock case raised a number of important issues. The first, and underlying one, was the fundamental first amendment question of the extent to which men may go in voicing their opposition to government policy and in supporting and in encouraging others-in this case, draft resisters-who would act, even illegally, in personal protest. Here the majority of the court of appeals predictably followed constitutional precedents calling for a weighing of the governmental interest and allowing the proscription of words that incite to illegal action. Chief Judge Aldrich, writing for himself and Judge McEntee, based his analysis on the assumption that the defendants' "ultimate" objective of expressing opposition to the war and to the draft was legal, but that "the means or intermediate objectives encompassed both legal and illegal activity."134 This underlying premise-that the concert of the parties was "bifarious," as the court called it, an "intertwining of legal and illegal aspects"135_presaged the conclusion. Once the question was framed in terms of whether "illegal" speech activity was protected, the result seemed inevitable. There was no question for the court but that there was power to punish "those who increase the likelihood of crime by concerted action." alternatives," such as prosecution for commission of the substantive offense when and if it occurred, simply "ignore[d] the potency of conspiratorial conduct; to wait for the substantive offense may be to wait too long. Congress has a right to prefer registrants to felons."137 For the majority, the constitutional judgment lay in "comparing the . . .

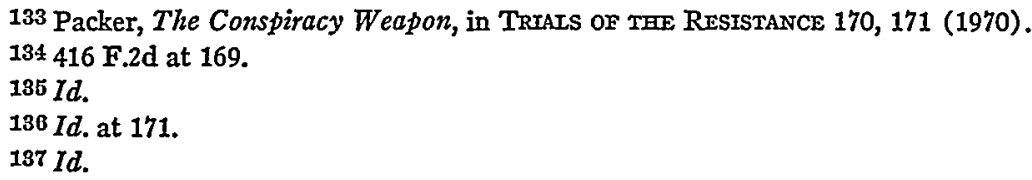


private and public interests," with the latter to prevail unless "insubstantial." Since the "maintenance of an army in peacetime [sic] is a valid, in fact vital, governmental function," ${ }^{\prime 138}$ deterrence of the substantive offense and prosecution of the conspiracy were permissible.

The requirements of Dennis and Yates were satisfied by the fact that the defendant's objectives all lay in the present, not the future, and any doubt as to either the imminency or the probability of accomplishment was stilled by brief mention of what the court called the "circumstances":

The existence of a large number of young men, perhaps impressionable, and in any event oriented in defendants' direction by natural self-interest, adequately distinguishes this case from Wood v. Georgia and Bridges v. California. In this context, the "soft sell" may be the most telling. ${ }^{139}$

The court gave only this much and no more for the "clear and present danger" test-in any form or variation.

The specific problem in Spock, of course, was not whether men can be punished for what they say, but whether they can be punished for what they agree to say, that is, whether the conspiracy sanction ought to be available to the government to prosecute a combination whose means or objectives are speech activity. The majority opinion in Spock discussed this issue, but only in conclusory and traditional form, involing the usual rhetoric surrounding conspiracy. The result was the customary adoption of conspiracy concepts-almost wholesale-into the speech area, without significant distinction between kinds of conspiracies. The premises predetermined the result in a manner not dissimilar from the World War I Espionage Act cases or the Communist Party cases. To be sure, for a brief paragraph or so, the court noted the potential for unfairness and abuse in the usually loose evidentiary rules governing conspiracy, but having alluded to the problem, it clearly prohibited government advantage only in a narrow area-with respect to intent, which is but one of a variety of crucial trial issues in the conspiracy case. ${ }^{140}$

$138 I d$.

$139 \mathrm{Id}$, at 1 '万 (footnotes omitted). Wood, 370 U.S. 375 (1962), and Bridges, 314 U.S. 252 (1941), were both decisions invoking the clear and present danger test to overturn convictions for contempt of court.

140 In a somewhat confusing passage, the court declared that there had been a "fundamental error in the government's approach" to the case. It was "improper" to adopt the "panoply of rules applicable to a conspiracy having purely illegal purposes" and to utilize the "statements of third parties alleged to be co-conspirators. . . The metastatic rules of ordinary conspiracy are at direct variance with the principle of strictissimi juris." 416 F.2d at 173. But if the words reflected a sense of the threat to first amendment freedoms inherent in the application of the usual evidentiary rules of conspiracy to cases involving speech, the context left it highly doubtful that the court 
The attempt to explain why it would not suffice to allow the government to prosecute only those who had actually engaged in illegal advocacy, counselling, or aiding and abetting, was essentially unsatisfying. Congress certainly does have the right to "prefer registrants to felons" but to leap from this to a conclusory allusion to the "potency of conspiratorial conduct" leaves a gap unfilled by intervening reasoning. It may indeed be that the "government's ability to deter and punish those who increase the likelihood of crime by concerted action has long been established," but it does not follow from this tradition that there should be an uncritical transfer of conspiracy doctrine into the area of speech crimes.

Perhaps it is too much to expect that a lower federal court would challenge directly the basic approaches taken in the World War I and Communist Party cases. Thus, a fairer appraisal of Spock may turn on an examination of the majority's more limited effort, its attempt to frame standards to distinguish the culpable from the guiltless in the context of a conspiracy that serves both legal and illegal purposes. As in Scales, the "mixed motives" of the defendants and the consequent involvement of the first amendment were seen "merely [to] present a more difficult problem of insuring that the government does not use its procedural advantages to expand the strict elements of the offense."141 The way to meet this "problem" was to take from Scales the requirement that the essential criminal intent be proven and judged strictly. The court elucidated the methods by which the "strictissimi juris" test of Scales and Noto could be met:

When the alleged agreement is both bifarious and political within the shadow of the First Amendment, we hold that an individual's specific intent to adhere to the illegal portions may be shown in one of three ways: by the individual defendant's prior or subsequent unambiguous statements; by the individual defendant's subsequent commission of the very illegal act contemplated by the agreement; or by the individual defendant's subsequent legal act if that act is "clearly undertaken for the specific purpose of rendering effective the later illegal activity which is advocated."142

Utilization of these tests would fully protect innocent participants in

was proposing radical surgery. Though the majority said that the statements of one defendant could not be used to prove the specific intent of another, it was far from clear that third-party statements could not be used for other purposes, e.g., to show the existence of an agreement or the illegality of the defendants' means or objectives. Because reversal was required in any event, the court was excused from the obligation to detail the extent to which the government's use of co-conspirators' statements may actually have been prejudicial.

141 Id. at 172 .

142 Id. at 173 (quoting Scales). 
the proper purposes of the agreement and would respond to the "legitimate apprehension ... that the evil must be separable from the good without inhibiting legitimate association in an orderly society."143

Judge Coffin's dissent rejected the reality of the protection afforded; it tellingly criticized the kinds of proof which the majority suggested for showing the requisite intent:

What are the implications of the three methods of activating one's signature to the "Call" to status as a fullfledged conspirator? To say that prior or subsequent unambiguous statements change the color of the litmus is to say that while one exercise of First Amendment rights is protected, two are not. To say that actual commission of illegal acts (i.e., encouraging turning in or burning draft cards-not specifically described in the "Call") renders culpable the more opaque original "agreement" is to say simply that the subsequent commission of one crime becomes suddenly the commission of two crimes. To say that "subsequent legal acts clearly undertaken for rendering effective the advocated illegal action" [my emphasis] renders retrospectively conspiratorial the earlier protected ambiguous advocacy is to say that two rights make a wrong. For example, were the janitor of Arlington Church to have signed the "Call" and subsequently to have volunteered his services to tidy the pews for the turn-in, he would have metamorphosed into a conspirator. ${ }^{144}$

The effect of the court's "delayed fuse approach to determining ... conspiratorial culpability" was correctly perceived by Judge Coffin as creating a "pronounced chilling effect-indeed that of a sub-zero blast —on all kinds of efforts to sway public opinion." 145

Even setting aside its inhibiting effects, the majority's approach seemed inadequate to accomplish the intended purpose. The immediate test of the court's standards came in their application to the case at hand; Spock had to be acquitted, according to the majority, because under the strictissimi standard there was insufficient proof to warrant an inference of his specific intent to adhere to the illegal portions of the agreement. That he had signed and helped draft the Call, and, indeed, had been one of the four signatories of the cover letter with which it was circulated, did not "evidence the necessary intent to adhere to its illegal purposes." Neither did his statement to a government agent that he was willing to do "anything" asked to further opposition to the war meet the test, for "specific intent is not established by such a general-

143 Id.

144 Id. at 187 (footnote omitted).

$145 \mathrm{Id}$. at 188. 
ization."146 Spock had attended and spoken at the Washington demonstration, though he played no role in the turn-in of draft cards either there or at the Arlington Street Church in Boston earlier. His speech was characterized as "limited to condemnation of the war and the draft, and lacked any words . . . of counselling. The jury could not find proscribed advocacy from the mere fact, which he freely admitted, that he hoped the frequent stating of his views might give young men 'courage to take active steps in draft resistance.' This is a natural consequence of vigorous speech," the court noted. ${ }^{147}$

Even if one is disposed to admire the court's restraint in refusing to affirm Spock's conviction, an examination of the basis on which contrary conclusions were reached as to Coffin and Goodman leaves a sense of more than vague unease. Coffin was also an originator of the Call, but the court chose to emphasize two other factors as sufficient to permit a different result than that mandated for Spock. First, Coffin had participated in the turn-in of draft cards in Boston and "this participation and assistance could well have been found to be aiding and abetting non-possession, a crime under the Selective Service Act." The significance of this conduct was that "because it was the very type of resistance that the agreement might have been found to contemplate, a properly instructed jury could find that Coffin had the requisite specific intent."148 Why the fact that Coffin may have been guilty of another crime made him convictable for conspiracy was not otherwise explained. Moreover, Ferber, who had arranged the Boston rally, had also assisted in the burning and surrender of draft cards on that occasion, but the meaning for him was inexplicably different than the same activity had been for Coffin. ${ }^{149} \mathrm{~A}$ second distinction the court seemed to seek to draw between Spock, on the one hand, and Coffin and Goodman, on the other, was that the latter pair had actually engaged in illegal counselling; their speeches-and indeed Goodman's own tract-had gone beyond what the court described as Spock's general denunciations of the war and the draft. The relevance of this too would be more understandable if the defendants had been charged with counselling or aiding and abetting instead of conspiracy.

Given the specific differences that can be identified, it appears that Spock was acquitted because, unlike Goodman and Coffin, he neither personally engaged in what the court was willing to consider

$148 \mathrm{Id}$. at 178.

147 Id. at 178-79.

$148 \mathrm{Id}$. at 178.

149 Ferber's acquittal was based on the court of appeals' conclusion that while he may have "engaged in a smaller conspiracy," he did not become part of the larger one which the government proved. See id. at 179. 
illegal counselling or aiding and abetting, nor gave any express indication of evil intent sufficient to satisfy the court. This result presents both theoretical and practical difficulties.

In holding that Coffin and Goodman could properly have been found guilty of conspiracy because they had committed another crime, the court belies its own stated assumption that the conspiracy indictment is necessary to thwart incipient or inchoate offenses. The pair could just as well have been charged with the discrete offenses of counselling or of aiding and abetting and it is difficult to know why such prosecutions would not have adequately protected the government's legitimate interests. ${ }^{150}$ But the court treated these other offenses as relevant only on the issue of intent. The unmistakable implication is that, given other sufficient evidence of intent and illegal purpose, conviction could have rested on proof of the agreement alone, without need to show that any actual illegal counselling (incitement) or aiding and abetting had occurred. Such traditional conspiracy logic-dispensing with the need for any illegal conduct beyond the agreement itselfwould allow conviction before the defendants had done anything more than merely agree to speak in the future, that is, even before drafting of the Call, much less its issuance, and before the Boston and Washington demonstrations. The unexamined constitutional problems which inhere in such a view are many and substantial. In any event it is certainly fair to doubt whether the First Circuit would allow a conviction to stand on such a set of facts, even if the existence of the agreement and the intent were clear; and in no event, it seems, would the court have upheld such a conviction without a much more careful analysis of the constitutional difficulties than it exhibited in the Spock opinion.

Examination of the other putative distinction between Spock and the non-acquitted defendants is also troublesome. To the extent Coffin and Goodman were the unwilling victims of their own explicit declarations of intent or purpose, the court leaves a situation in which, after its decision, only one untutored in the law would expose himself to conviction. The implication from comparison of Spock with Goodman and Coffin is that had the latter two defendants been only slightly more cautious in use of a few key words or sentences, they might have escaped conviction on the conspiracy charge altogether. While the meaning of speech does indeed depend on the words used, the context

150 The availability of alternative means of protecting the government's interest without restricting speech to such a great extent is highly relevant to the constitutional propriety of use of the conspiracy prosecution. See United States v. Robel, 389 U.S. 258 (1967); Aptheker v. Secretary of State, 378 U.S. 500 (1964); Shelton v. Tucker, 364 U.S. 479, 488 (1960). See generally Note, Less Drastic Means and the First Amendment, 78 YAIE L.J. 464 (1969). The dissent in Spock raised the point, but obviously failed to persuade the majority. 
cannot be irrelevant. Criminality ought not to turn on one's subtlety in avoiding the use of particular phraseology, while conveying substantially the same meaning. If the strictissimi standard does require such explicitness and precludes resolution of any ambiguity against the defendant, it becomes comparatively easy to escape conviction whatever the unuttered intent. Conversely, to allow an inference of specific intent to be drawn from words of lesser clarity, or from more general statements would seem to defeat the court's very purpose in eliciting the strict test. A less wooden standard would seem to have compelled the court to allow resubmission of Spock's guilt to another jury, along with that of Coffin and Goodman. In sum, it is hard to see how the court's rule can work to protect the innocent without also insulating the guilty, but sophisticated; or how it can reach the latter without also jeopardizing the former.

It is possible, of course, to venture another, "psychological" explanation of the court's rather strained efforts to distinguish among the defendants. On the one hand, the court was doubtless sensitive to the first amendment interests at stake and to the fact that the defendants were far from being ordinary criminals. Yet, it may have felt itself trapped, together with Coffin and Goodman, by those defendants' own words-by their explicit or near explicit declarations of intent to counsel and to aid and abet draft resisters to violate the Selective Service law. Moreover, Coffin's direct challenge to the government to prosecute him may have left the court uncomfortable at the prospect of allowing the defendants, on appeal, to deny the literal meaning of their own declarations and belatedly to give them another, more innocent cast. Judges Aldrich and McEntee may thus have felt bound to do no less than to take the defendants at their word. At least they may have thought themselves precluded from denying the jury an opportunity to do so. ${ }^{151}$ The result nonetheless was one that fairly invited the dissent's comment that the court's acquittal of Spock and Ferber was "the product of its own generosity rather than the inevitable result of its rationale."152 But for precedential purposes, at least, speculation as to the wellsprings of the court's motivation is less significant than its articulated legal structure.

At bottom, there remains the strong sense that there was little if anything to justify finding significant differences in intent among the

151 Thus, at one point, the court declared "we do not think of Coffin as one to run with the hare and hold with the hounds," 416 F.2d at 178; in like tone, it also noted that Coffin and Goodman had "publicly asserted that they were placing their own necks on the block" and that they "should not now be heard to say that no axe was involved," id. n.29.

152 Id. at 191. 
four convicted defendants. The court's disparate conclusions as to the various defendants provided little in the way of reliable guidance for the future-either to other courts in other cases, or, even more importantly, to other dissenters in other situations. This is no small failing in a constitutional area in which certainty is to be especially prized; there is no virtue in creation of a penumbra of vagueness around the first amendment. The objective should be to maximize the area of permissible and freely exercisable expression, not to deter and keep people well clear of the line of illegality.

\section{The Dissent's Test}

While the majority asked whether there was "reason or authority barring prosecutions for public conspiracy in the speech-opinion field," and answered that question in the negative, the issue for Judge Coffin, in dissent, was whether application of conspiracy doctrine was compelled in such a case. The dissent placed primary emphasis on the threat to expression and association and, as noted, found the majority's ostensible safeguards inadequate to their purpose. For Judge Coffin, then, all of the convictions should have been reversed and acquittals directed for all the defendants because use of conspiracy doctrine was "not compelled by conspiracy precedents, not consistent with First Amendment principles, not required to deal effectively with the hazard to public security, and not capable of discriminating application as between the culpable and the innocent."153

Despite the breadth of his disagreement with the majority, Judge Coffin stopped short of saying that "the law should recognize no overt conspiracy in the sensitive area of public discussion and opinion."154 To do that, he thought, would go "too far"; it would allow the public nature of the group to "confer an immunity both on nefarious joint undertakings and absolute protection to criminal enterprise not vouchsafed by the First Amendment even for individual speech."155 Giving heavy emphasis to the openness of the combination before him, he pointed to five characteristics as distinguishing the alleged conspiracy in Spock from the combinations presented in the other speech and nonspeech cases upon which the majority had relied:

Here we confront a "conspiracy" where (1) the effort was completely public; (2) the issues were all in the public domain; (3) the group was ill-defined, shifting, with many 
affiliations; (4) the purposes in the "agreement" are both legal and illegal; and (5) the need for additional evidence to inculpate-notwithstanding the absence of a statutory requirement for an overt act-is recognized. ${ }^{156}$

It is true, of course, that openness is hardly a typical feature of the usual criminal conspiracy, but as the majority responded, lack of secrecy is not alone enough to warrant immunity, especially where achievement of the conspirators' objectives requires some public communication. What, then, does the public nature of the group's actions suggest? Certainly, the government could be, and presumably was, aware of the assertedly subverting actions of the defendants. In some cases, this might allow it to take appropriate non-prosecutorial steps to forestall the objectionable consequences. It is not apparent, however, that immediately effective alternatives were available to the government in the Spock situation. ${ }^{157}$

The dissent also suggested that, given its "openness," the putative "danger" or "threat" posed by the conspiracy was diminished. That, of course, may be so. But the accuracy of the assertion neither was selfevident in the Spock case itself, nor will it invariably be true. To the extent that the group is engaged in speech-in an attempt to persuade-its very strength and potential effect may well depend on its success in securing wide dissemination of its message. Thus, in many instances, the open nature of the efforts may enhance the apprehended danger. Conversely, the absence of public notice of the conspirators' actions, when directed to speech, may be more a function of their ineffectiveness and the consequent insignificance of the threat they pose, than of anything else. Moreover, there is often an obvious relationship between the notoriety of the "conspirators" and the extent of public attention accorded their speech or actions. Accordingly, the "publicness" criterion may tend toward protection of those who are least in need of it. While the Spock case hardly illustrates the point, it is perhaps the relatively impotent and powerless who more often become victims of government suppression.

To be sure, Judge Coffin was probably directing his remarks to the fact that the defendants made no effort at concealment, rather than to the fact that their activities were widely known. But, again, this seems an inadequate base on which to rest a constitutional distinction. The

156 Id. at 186.

157 Of course it is always open to the government to rebut the defendants' speech, i.e., to enter the "market place of ideas." More specifically, it is conceivable that if the problem were thought acute, Congress could have been asked to increase the penalties for draft evasion. 
attempt to maintain secrecy of identity in the political or speech area is as likely a consequence of fear of reprisal as of illegal purpose. ${ }^{168}$

The open character of the activity does, of course, emphasize the constitutional interests at stake. To the extent that the conspiracy is "public" it is likely to contribute to the general political dialogue, to the "market place of ideas," and thus even more obviously serve the very core interests the first amendment was intended to foster. The focus is the same with respect to Judge Coffin's points that the "issues [to which the alleged conspiracy was directed] were all in the public domain," that the agreement, if any, had both "legal and illegal" purposes, ${ }^{159}$ and that the membership of the "conspiracy," was shifting and ill-defined as is typical of politically oriented groupings. These are all factors which testify both to the political nature of the case and the importance of casting the rule in favor of allowing the speech. It does not follow, however, that the propriety of the charge of conspiracy in speech cases should turn on the extent to which the issues have already become public, or on the extent to which the participants are wellorganized, have shown a readiness to go before a large audience, or an ability to reach a broad segment of the public. Use of conspiracy doctrine would seem neither more nor less proper, for example, in the case of a small, cohesive group composed of a few individuals distributing anonymous leaflets in an attempt to alert readers to previously unrecognized issues. Concentrating as he does, on the particular aspects of the campaign conducted by the Spock group, Judge Coffin's tests seem inadequate to establish justifiable distinctions among various kinds of speech conspiracies.

\section{Conspiracy and Spetch Crimes: Some Conceptual} and Practical Problems

The courts, as it thus appears, have upheld use of conspiracy to prosecute for past illegal utterances while citing reasons for its use as an inchoate offense. At the same time, they have failed to perceive the difficulties of applying first amendment standards where projected or future advocacy has not yet occurred. Of course, Justice Jackson writ-

158 To fail to take account of the need for self-protective secrecy felt by those who disseminate unpopular ideas seems inconsistent with Talley v. California, 362 U.S. 60 (1960), in which the Supreme Court held invalid, on its face, a California statute which banned distribution of anonymous political literature. The Court's clear recognition of the interest in circulation of ideological or political tracts unidentified as to individual source tends to undercut, somewhat, one possible rationale of Coffin's distinction. See also Bates v. Little Rock, 361 U.S. 516 (1960), and NAACP v. Alabama, 357 U.S. 449 (1958). But cf. Golden v. Zwickler, 394 U.S. 103 (1969), in which the Court avoided the need to reaffirm and apply, or reject Talley by finding the absence of a case or controversy. 159416 F.2d at 186. 
ing in Dennis, seemed to recognize the difficulty, but used it as a basis for rejecting the then applicable constitutional test; having touched the problem, he left speech the clear loser.

The other possible exception may be Yates, in which Justice Harlan sought expressly to reserve the question of constitutional propriety of a conviction involving a conspiracy to advocate in the future and to limit the broad language of Vinson in Dennis ascribing criminality to the conspiratorial agreement alone. Harlan emphasized that both Dennis and Yates involved advocacy which had already taken place. But even this seeming reticence to carry conspiracy doctrine to the limits of its logic was apparently either forgotten or overcome by the time Harlan wrote for the Court in Noto and suggested that some provisions of the Smith Act reached the still executory agreement. Yates itself contained language by Harlan seemingly inconsistent with his recognition of the distinction between a conspiracy to engage in present advocacy and one to engage in such speech only in the future. Following a review of the evidence, he reiterated the traditional common law rule that the overt act, required under the statute, ${ }^{160}$ need not "be the substantive crime charged in the indictment as the object of the conspiracy"here, advocacy-nor need it "taken by itself, even be criminal in character."101 The analysis harks back to the idea of conspiracy as an inchoate offense. Yates alone is confusing enough; when coupled with the retraction in Noto, the matter is left quite unclear.

The language and rationale of Spock, like Dennis and the earlier decisions, also seem to support prosecution without any illegal speech having occurred. The thrust of the $S p o c k$ court, so self-consciously diligent in its attempt to restrict the scope of conspiracy in the first amendment area, pushes inevitably to criminality of the still silent combination. Though the First Circuit emphasized that illegal counselling and aiding and abetting had in fact taken place, it explicitly relied on the commission of these other offenses only as fitting within one of its three possible rubrics for proving specific intent. There were two other permissible avenues outlined in the opinion: proving the defendant's "prior or subsequent unambiguous statements" or his having engaged in some other "legal act" undertaken to implement the conspiracy's illegal purpose. Neither would have required proof of illegal

160 During part of the period covered by the indictment in Yates, the recodified Smith Act did not contain a conspiracy provision and thus the conspiracy allegation was laid under the generally applicable federal conspiracy statute, 18 U.S.C. $\$ 371$ (1970), which, unlike the original Smith Act, required proof of an overt act. See 354 U.S. at 301-02 n.1.

161354 U.S. at 334. 
speech by any of the defendants. This, of course, fits the underlying conception of conspiracy; the illegality lies in the agreement itself without regard to its implementation.

The unmistakable logic of Spock makes prosecution of a wholly executory speech conspiracy a real possibility; it also makes clear that the elements which need to be proven to support conviction even in the case of a partially executed conspiracy are precisely the same. There is no need-whatever the psychological benefit accruing to the prosecution in doing so where it can-to prove that the defendants have engaged in any illegal speech. The case is complete, and conviction proper, when it is shown merely that the defendants have agreed to engage in illegal speech, that they have agreed to incite.

So conceived, speech-conspiracy raises serious problems. Of course, it is possible to read the cases as confined to their facts and imply a requirement that the occurrence of illegal speech is a prerequisite to conviction for conspiracy to commit a speech crime. To do so would be salutary. But it would work a dramatic change in the perceived nature of the offense, barring use of conspiracy to prosecute inchoate crime in the speech area. Moreover, reading any such limitation into the decisions would run directly contrary to their words and logic. It is appropriate and necessary, therefore, to consider further the difficulties presented when conspiracy to advocate is treated as a punishable inchoate offense.

\section{A. The Double-Layered Risk}

Notwithstanding the common rhetorical flourishes concerning the criminality of the agreement itself, punishment of conspiracy as a separate crime is justified, if at all, not because of any actual harm the conspiracy has caused society, but because of the harm it threatensthe danger it creates of collective or individual injury in the future if and when active measures are taken to carry it out. Once the agreement and requisite intent are shown, the risk of such injury and the chance that harm will actually ensue are thought-rightly or wrongly - to be sufficiently great, because of the combination, to warrant imposition of the criminal sanction. The difficulty is that the conclusion which may be warranted in other contexts, involving other kinds of conspiracies, has been too readily applied in the speech context.

The justification for intervening through the criminal process in the case of unexecuted conspiracy to murder, for example, is that should the conspirators carry out their plans immediate and irrepara- 
ble harm is likely to result to the victim. ${ }^{162}$ The case of conspiracy to commit a speech crime is hardly comparable. Prosecution for conspiracy to incite to violence must be justified on remoter grounds. Just as conspiracy itself is an inchoate crime, so too is incitement, like most other speech crimes. ${ }^{163}$ Thus, to charge a speech conspiracy is to load one inchoate offense upon another. Even if the conspirators act, the immediate result is not violence but the impact on others of the assertedly inciting words. These may or may not prove effective in achieving the conspirators' ends. Another stage must be reached before the harm-here violence- befalls; the listeners must themselves move to do that which the conspirators seek to induce.

A conspiracy to incite is thus an offense twice removed from the substantive crime, an offense doubly distant from the evil sought to be avoided. Even if the inciter is thought to be no less culpable than the immediate perpetrator of the ultimate crime, he is at least one step further removed from its commission. And the one who conspires to incite is still another move distant from the overt commission, for he is only planning to induce another to do the prohibited act. The conspiracy originates the risk that the conspirators will actually carry out their plan to incite, i.e., that they will in fact create a second risk, the risk that others will be moved to commit the substantive offense. The same is obviously true with respect to the crime of conspiring to counsel commission of a crime, one of the charges brought against Dr. Spock and his co-defendants. Conspiring to aid and abet may be slightly different; to the extent, however, that it contemplates no active assistance or initiative beyond speech, it does not go beyond the conspiracy to incite. ${ }^{164}$ In any event, a conspiracy to aid and abet still requires the intervention of another will, the need for another to act and to perpetrate the ultimate crime. So here too, there remain two steps prior to maturation of the actual harm; again, there are two calculations of probability.

102 See text accompanying notes 21-29 supra.

163 Obscenity and libel/slander-both speech crimes-may be different. In the latter case, the injury to reputation may be viewed as flowing directly from the utterance and in that sense is immediate. If the ultimate evil of obscenity is its asserted propensity to move others to commit sex crimes, for example, then it is like incitement; on the other hand, if the harm is thought to be an offense to the sensibilities of others, it is direct and is complete with the hearing.

164 The federal "aiding and abetting" statute, 18 U.S.C. $\$ 2$ (1970), is broad enough to encompass both speech and other affirmative assistance:

(a) Whoever commits an offense against the United States or aids, abets, counsels, commands, induces or procures its commission, is punishable as a principal.

(b) Whoever willfully causes an act to be done which if directly performed by him or another would be an offense against the United States, is punishable as a principal. 
It is significant on several counts that the risk to which the prosecution responds is double-layered when the object of the conspiracy is a speech crime. First, whatever justification the government seeks to put forth as warranting the intrusion into the first amendment area is necessarily diminished. Whether under the ad hoc balancing test, the clear and present danger test, the modified Dennis test, or the probability-imminency standard of Brandenburg, the threat to the government interest must be reduced, if only because one additional step removed from actual maturation into realized harm.

Second, the increased remoteness of the crime of conspiracy to incite from the ultimate evil not only points to a probable reduction of the real danger to which the government is seeking to respond and therefore to a lessening of the justification for the suppression of speech, but also suggests the increased propriety of weighing alternative-and less oppressive-means of protecting legitimate governmental interests, a consideration of constitutional magnitude. ${ }^{105}$ The double-layered nature of a conspiracy-speech crime immediately points up the possibility of deferring a charge or finding of criminality until the incitement stage is actually reached. In evaluating the propriety of deferral, however, one must take account of two factors-the extent to which the proferred alternative represents a loss of effectiveness in protecting a legitimate governmental interest and the extent to which it furthers first amendment or other constitutional interests. To the extent the loss to the government is great or the gain to basic rights small, there is little justification for urging the alternative.

\section{B. Predictive Illegality}

The very possibility of convicting someone for having participated in a still unexecuted conspiracy to incite (or one in which there is no proof that illegal incitement has occurred) raises practical and legal problems that come close to placing the defined crime beyond legitimate comprehension. ${ }^{166}$ One way to describe the issue, albeit inade-

165 See note 150 supra.

168 It should normally make no difference for constitutional purposes whether the conspiracy provision under which a specific speech-conspiracy charge is laid appears in the same statute which proscribes the substantive offense, as in the original Smith Act, or whether it is a general section, such as 18 U.S.C. § 371 (1970), applicable to conspiracies to commit any substantive offense. Even where the legislative decision to include conspiracy within the substantive statute took account of its application to speech crimes and represents a conscious election, it should not foreclose questions as to the validity of the provision either on its face or as applied. Certainly, the legislative determination should not be treated as resolving either facial problems of vagueness (overbreadth or uncertainty of definition) or the propriety of application in any particular case. Even in Dennis, in applying the original Smith Act (for which the Congress quite clearly had a specific, extant "conspiracy" in mind), the Supreme Court thought it necessary to find the existence of a "clear and present danger." At most, the legislative 
quately, is to label the problem as one of vagueness. ${ }^{107}$

The attempt to define the limits of speech, to specify the nature and type of words or related conduct which lie beyond the bounds of first amendment protection, has been one of the vexing challenges of constitutional adjudication. While Yates, reinforced by Brandenburg, drew the line between illegal incitement and permissible speech so as to condemn only "advocacy of action," the opinion of the Court at the same time conceded that the distinction was at best "subtle and difficult to grasp."168 The conceptual differences, if not the practical ones, between mere advocacy of ideas and incitement are shaded and in any given case it may be extremely difficult to decide on which side of the line the challenged expression may fall. The determination will often require the most precise examination of the exact words of the defendant and the setting in which they were spoken; even then there may still be substantial ambiguity.

When the charge is conspiracy to incite, there is no longer any need to prove that words of incitement or advocacy have actually been used. Instead, the test is whether the defendants intended or agreed to use such words. If there is often a serious problem in determining whether specifically given speech constitutes incitement, the difficulties

choice should be read to speak to the special danger of group action of a particular nature. But even so limited, there are still substantial questions, as for example, for how long into the future should the determination be viewed as valid? See generally Linde,

"Clear and Present Danger" Reexamined: Dissonance in the Brandenburg Concerto, 22 StaN. L. REv. 1163 (1970).

167 The term "vagueness" incorporates concepts of first amendment "overbreadth" and due process lack of certain definition sufficient to guide prospective offenders, courts, and juries; it is used here to refer to both. See generally Note, The Void-for-Vagueness Doctrine in the Supreme Court, 109 U. PA. L. Rev. 67 (1960); Note, The First Amendment Overbreadth Doctrine, 83 HARV. L. REv. 844 (1970). It is well settled that "[t]he constitutional requirement of definiteness is violated by a criminal statute that fails to give a person of ordinary intelligence fair notice that his contemplated conduct is forbidden ...."United States v. Harris, 347 U.S. 612, 617 (1954). Due process is violated if the law "leaves the public uncertain as to the conduct it prohibits or leaves judges and jurors free to decide, without any legally fixed standards, what is prohibited and what is not in each particular case." Giaccio v. Pennsylvania, 382 U.S. 399, 402-03 (1966). See also Herndon v. Lowry, 301 U.S. 242, 261-64 (1937). The evil, in first amendment terms, of a vague statute is not only that it "lends itself to selective enforcement against unpopular causes," NAACP v. Button, 371 U.S. 415, 435 (1963), but that it reaches both protected and unprotected conduct-speech "which legitimately may be proscribed" as well as speech "which may not be proscribed," Keyishian v. Board of Regents, 385 U.S. 589, 609 (1967). And the very uncertainty inhibits exercise of rights of speech and association. As Justice Frankfurter has written:

Prohibiting, indiscriminately, activity within and without the sphere of the Fourteenth Amendment's protection of free expression, those statutes had the double vice of deterring the exercise of constitutional freedoms by making the uncertain line of the Amendment's application determinative of criminality and of prescribing indefinite standards of guilt, thereby allowing the potential vagaries and prejudices of juries, effectively insulated against control by reviewing courts, the power to intrude upon the protected sphere.

Shelton v. Tucker, 364 U.S. 479, 492 (1960) (dissenting opinion).

168354 U.S. at 326. Justice Clark confessed that the "artillery of words" in Yates left him "confused" and that "the distinctions are too "subtle and difficult to grasp." "Id. at 349-50. 
of making such a judgment become nearly insurmountable when the exact words are not even before the court. The judge and jury are left to infer the content of the undisclosed speech from the defendant's declared intent, or, as may be more likely, from his intent as itself inferred from other evidence. When the speech being tested is merely a projection from such questionable bases, there is an almost uncontrollable freedom to wander at large into impermissible areas. ${ }^{169}$ And, of course, it is highly questionable whether any effective review can be exercised in the face of such a process. ${ }^{170}$

Moreover, in order to conclude that any given set of words is inciting, it is necessary not only to know what those words are, but to have some basis for making a judgment about their effect. The speech of the defendant must be placed in context both to understand its meaning and to judge its probable impact. While the status of the "clear and present danger" formulation is uncertain, present first amendment standards surely seem to require some measurement of the probable reaction of probable listeners to any given set of allegedly inciting words. ${ }^{171}$ But absent a setting, an audience, and the speech itself, the judgment becomes even more than prophetic; it is fantasy. ${ }^{172}$ One

169 The words of the Supreme Court in Speiser v. Randall, 357 U.S. 513, 526 (1958), are apposite:

The vice of the present procedure is that, where particular speech falls close to the line separating the lawful and the unlawful, the possibility of mistaken fact-finding-inherent in all litigation-will create the danger that the legitimate utterance will be penalized.

See also Freedman v. Maryland, 380 U.S. 51, 58 (1965); Marcus v. Search Warrant, 367 U.S. 717, 732 (1961).

170 For a discussion of the Supreme Court's use of the "void for vagueness" doctrine as a device to control unreviewable decisionmaking, particularly by state courts (also a potential source of speech-conspiracy cases), see Note, The Void-for-Vagueness Doctrine in the Supreme Court, 109 U. PA. L. REv. 67, 104-15 (1960).

171 The Supreme Court's ruling in Brandenburg v. Ohio, 395 U.S. 444, 447 (1969), that the Constitution allowed proscription only of advocacy which "is directed to inciting or producing imminent lawless action and is likely to incite or produce such action" certainly indicates that an evaluation must be made of the probable effect of the challenged speech. Whether or not Brandenburg should be read as revitalizing the "clear and present danger" test is another question. The concurring opinions of Justices Black and Douglas in Brandenburg are based on their assumption that the case does not have that consequence.

172 Cf. Herndon v. Lowry, 301 U.S. 242 (1937), reviewing a conviction under a Georgia statute proscribing "[a]ny attempt, by persuasion or otherwise, to induce others to join in any combined resistance to the lawful authority of the state," id. at 246 n.2. Though the state court read the statute to cover only violent resistance, it also ruled that it was enough if the violence might be expected to occur at any reasonable time in the future. Herndon v. State, 179 Ga. 597, 600, 176 S.E. 620,622 (1934). In overturning the conviction on "vagueness" grounds, the Supreme Court declared:

The statute, as construed and applied in the appellant's trial, does not furnish a sufficiently ascertainable standard of guilt. The Act does not prohibit incitement to violent interference with any given activity or operation of the state. By force of it, as construed, the judge and jury trying an alleged offender cannot appraise the circumstances and character of the defendant's utterances or activities as begetting a clear and present danger of forcible obstruction of a particular state function. Nor is any specified conduct or utterance of the accused made an offense. 
is forced back even beyond what was done in the World War I Espionage Act cases; there at least the Court read intent and effect from the defendants' actual words; here, the words themselves are inferred from the intent, often itself an inference, and then effect is inferred from the assumed speech.

Even when intent appears clear, the attempt to measure the character and consequences of future advocacy is a hazardous business. The distance between intent and realization can widen to a chasm and the conspirator may either change his text (assuming he has even prepared one in advance) or lose his courage. Moreover, his preparatory rhetoric-possibly the very basis of the conspiracy charge-may overrun his actual intent, as well as his actual performance, should it ever, in fact, occur. The problem is unusually keen in this day of escalated rhetoric and devalued epithet, when overstatement comes close to being the rule, rather than the exception, among those most likely to be the targets of efforts at suppression. ${ }^{173}$

It is possible of course to say that since it is the agreement which is being punished in the conspiracy case, the fact that no incitement has actually occurred is of no moment and should give no reason for pause. But this merely begs the question, since the punishment is based upon an assumption that the parties have agreed to do something illegal, a determination which, as has been pointed out, can not be readily made in advance in the speech context.

The risk is apparent. The defendant can be found guilty of conspiracy to incite even though the words he intended to utter might not have been criminal if actually spoken and judged in actual context.

... If, by the exercise of prophesy, he can forecast that, as a result of a chain of causation, following his proposed action a group may arise at some future date which will resort to force, he is bound to make the prophesy and abstain under pain of punishment, possibly of execution. ... The question thus proposed to a jury involves pure speculation as to future trends of thought and action. ... The law, as thus construed, licenses the jury to create its own standard in each case.

The statute, as construed and applied, amounts merely to a dragnet which may enmesh anyone who agitates for a change of government if a jury can be persuaded that he ought to have foreseen his words would have some effect in the future conduct of others.

301 U.S. at 261-64.

173 The drafters of the A.L.I. Model Penal Code have noted:

The problem is in preventing legitimate agitation of an extreme or inflammatory nature from being misinterpreted as solicitation to crime. It would not be difficult to convince a jury that inflammatory rhetoric in behalf of an unpopular cause is in reality an invitation to violate the law rather than an effort to seek its change through legitimate criticism. Minority criticism has to be extreme in order to be politically audible and if it employs the typical device of lauding a martyr, who is likely to be a lawbreaker, the eulogy runs the risk of being characterized as a request for emulation.

No solution to this problem has been found which is entirely satisfactory.

Moder Penal Code § 5.02, Comment at 88 (Tent. Draft No. 10, 1960) (footnote omitted). 
Thus, unspoken words may be afforded less protection than actual speech itself.

In the absence of a demonstration that prohibited advocacy has taken place, it becomes clear that the punishment in a speech conspiracy case is for shared intent. But this is simply another way of stating the underlying theory of all conspiracy prosecutions. The difference here, of course, is that what is being suppressed is speech, not for example, an agreement to commit murder. The consequences are substantial. With a conspiracy to murder one faces a potential crime of finite proportion and of near unmistakable content. There is little, if any, risk that either the defendants themselves, or the court or jury, will mistake the criminality of what the defendants propose to do. The probability of such a mistake both by the alleged conspirators and by the trier of fact is very high, however, in the case of a conspiracy to incite.

Of course, in both instances, there may be doubt about whether the defendants have really agreed and, if so, about the firmness of their intent. ${ }^{174}$ Certainly, the margin for tolerance of error favoring the defendant is much greater in the incitement case than in the murder (or robbery or embezzlement) case, for the risk in the former is doubly inchoate and presumably there will almost always be another chance for official intervention. Once the conspirators act to effect a murder, however, the harm is likely to be irreparable.

Finally, and not least of all, the preferred position of first amendment rights should lead to casting the balance in favor of protection of speech rather than suppression. This is not to say that incitement itself is protected, but that the utilization of the conspiracy device to suppress it is improper. ${ }^{175}$

174 The imprecision inhering in the concepts of "agreement" and "intent" in conspiracy only add to the vague uncertainty. As one commentator has written:

If the prohibited purpose is clearly set forth in the conspiracy statute, the difficulties are solely those involved in applying the concept of an agreement. When, however, unlawful purpose is vaguely stated, the contours of "conspiracy" become ever more vague, and the dividing line between intent, now designated "purpose," and act, now termed "agreement," tends to disappear. Added to the problems inherent in a concept created to deal with potential antisocial action are new ones which arise when it is not at all clear what kind of antisocial action is threatened.

Goldstein, supra note 13, at 407. And again:

Yet "agreement" is almost as much a theoretical construct as the "intent" it is supposed to carry over the threshhold from fancy to fact. Indeed, in most cases, it is proved by the very same evidence from which intent will be inferred. Thus, instead of anchoring intangible intent to a tangible act, the law of conspiracy makes intent an appendage of the equally intangible agreement. By pouring the same proof into the mold of "agreement" and by calling that "agreement" an "act"-passive though it may be-courts foster the already elaborate illusion Id. 410 .

that conspiracy reaches actual, not potential, harm.

${ }^{175}$ The Scales-Noto-Spock requirement of strict proof of specific intent may 


\section{C. "Prior Restraint"}

The importation of conspiracy into the speech area has been condemned as an unconstitutional "prior restraint."176 And, in the sense that it can apply and work punishment for intent and agreement alone, before any illegal speech occurs (or without proof that it has), it is clearly a before-the-fact sanction. In such a situation, there can be no pretense that the defendants are being tried for what they have already said. But, as has been noted, the label "prior restraint" is not a "selfwielding sword" or a "talismanic test,",177 automatically requiring a judgment of impropriety. There remains the "duty of closer analysis and critical judgment in applying the thought behind the phrase."178

In fact, criminal conspiracy seems at first to be quite different from the usual prior restraint case which typically involves some before-the-fact civil injunctive prohibition on speech. The conspiracy case is criminal and, while one purpose may be to deter speech as with an injunction, another is to punish for the ostensibly complete criminal conduct involved in having combined for an illegal purpose. The constitutional concept of prior restraint has normally been thought to ap-

arguably compensate, in part, for the generic imprecision of speech-conspiracy and the almost inevitable uncertainty as to the nature of unproven speech and the reality of the prophesized danger. By no means, however, does it solve the problem, especially given the inferential subjectivity of the intent determination itself. The general tendency to incorporation of a requirement of intent, mens rea, or "scienter," into statutes challenged as "vague" has been noted elsewhere. See Note, The Void-for-Vagueness Doctrine in the Supreme Court, 109 U. PA. L. REv. 67, 87 n.98 (1960). The author suggests that this attempted solution is less than satisfactory and comments:

In any event, "scienter" has become a recognized element of the lore of vagueness, and represents at its best, a tool to be designedly used in the service of other ends; at its worst, a port of entry for the ethical predilections of the then sitting Court.

The suggestion is not unwarranted. The element of intent-though in certain instances it may function as an exonerating factor-can also serve to shift the focus of inquiry and function as a subjective justification for invocation of legal proscriptions where the substantive threat of harm is realistically lacking. The World War I cases, with their emphasis on state of mind and their minimization of any real requirement of danger, are an example. Spock itself may be another. It is simply too easy to assume that proof of specific intent eliminates other difficulties. Doubt as to the reality of the danger, concern over inhibiting the innocent, and worry that conviction may be based on participation in protected activity can be all salved by compelling a finding of specific intent so that at very least, we can say that we are punishing only those whose motives are faulty. The result may be conscience-easing, but it hardly substitutes for facing the difficult constitutional and practical problems presented by the very nature of the crime. In sum, undue reliance on proof of intent may operate to allow convictions not otherwise supportable, or, as in Scales, Spock, and Noto, to allow adoption of constitutional rules of a doubtful nature.

176 Justice Black applied the label in Dennis, 341 U.S. at 579 . See also Note, Conspiracy and the First Amendment, 79 YALE L.J. 872, 881 (1970).

177 Kingsley Books, Inc. v. Brown, 354 U.S. 436, 441 (1957).

178 Id. at 441. The Court also quoted with approval, id. at 442, Professor Freund's observation that: "What is needed is a pragmatic assessment of its operation in the particular circumstances. The generalization that prior restraint is particularly obnoxious in civil liberties cases must yield to more particularistic analysis ..." Freund, The Supreme Court and Civil Liberties, 4 VaND. L. Rev. 533, 539 (1951). 
ply mainly in the case of administrative censorship ${ }^{179}$ (though the generating Supreme Court case, Near v. Minnesota, ${ }^{180}$ involved a judicial injunction), and to have no application to criminal sanctions. Indeed, the criminal case brought subsequent to publication is usually posed as the proper alternative to prior civil or administrative inhibition.

Where licensing schemes or systems calling for prior administrative approval of speech have been struck down, it has often been because of defects of design rather than the inherent unconstitutionality of the concept underlying the restriction. Thus, findings of impropriety have been based on the absence of an adequate standard to control the exercise of administrative discretion, ${ }^{181}$ the lack of precision with which the proscribed speech is described, ${ }^{182}$ or the absence of effective or sufficiently prompt judicial review. ${ }^{183}$ Significantly, not all prior restraints are unconstitutional; the Court has indicated that a scheme of prior control, with affirmative prohibition in advance of publication or public showing, would be permitted so long as strict procedural, burden of proof, and timing requirements were met. ${ }^{184}$

It would seem that the typical criminal conspiracy case would meet the necessary procedural requirements: the trial is judicial and prompt review is normally accorded. Moreover, the burden is on the government to submit proof beyond a reasonable doubt, and jury trial is available - two factors which, given the traditional reasoning about prior restraints, would seem to favor constitutionality as against the

179 See, e.g., Emerson, The Doctrine of Prior Restraint, 20 Law \& Contemp. Prob. 648, 655 (1955):

The clearest form of prior restraint arises in those situations where the government limitation, expressed in statute, regulation, or otherwise, undertakes to prevent future publication or other communication without advance approval of an executive official.

The doctrines barring prior restraint, of course, do not establish that the state cannot regulate, prohibit, or punish speech; rather they deal with the questions of when and how it may be done. The issues raised in the prior restraint cases go to the method, timing, and procedure of the restraint, not to the kinds of speech which are suppressible. But cf. note 185 infra.

180283 U.S. 697 (1931). It should be noted that criminal conspiracy goes even beyond the restriction held unconstitutional in the landmark Near case. There the Court struck down as an improper "prior restraint" a Minnesota statute deciaring regular publication of certain kinds of material ("obscene, lewd and lascivious" or "malicious, scandalous and defamatory") to be an enjoinable nuisance. It appeared, under the statute, that prior publication of the prohibited type was a prerequisite to the action; a mere showing that the defendant intended to publish such material was apparently not enough, as it would be in a speech-conspiracy action.

181 See Kunz v. New York, 340 U.S. 290 (1951); Niemotko v. Maryland, 340 U.S. 268 (1951).

182 See Joseph Burstyn Inc. v. Wilson, 343 U.S. 495 (1952).

183 See Teitel Film Corp. v. Cusack, 390 U.S. 139 (1968); Freedman v. Maryland, 380 U.S. 51 (1965).

184 See cases cited note 183 supra. 
administrative or civil proceeding tried to an agency or judge under a less restrictive burden of proof standard.

In addition, the primary concern of the prior restraint cases seems to be the fear of largely unrestricted censorship, of the need to submit proposed publications for approval (especially administrative) before dissemination, a problem not really present in the typical conspiracy case. This is not to say, however, that the learning surrounding prior restraint is inapplicable to the speech-conspiracy case.

The arguments that can be made in favor of a prior civil determination of suppressibility are precisely the ones which point to the impropriety of the conspiracy sanction. Prior civil restraints, if properly surrounded with procedural protections, have the advantage of providing a judicial resolution in advance of publication, expression, or showing, without the publisher, seller, speaker, distributor, or movie theater operator having to undergo the risk of criminal prosecution; punishment results only if the scheme is ignored altogether or if a specific restrictive order is violated. Such assertedly compensating advantages do not exist with criminal conspiracy which presents the unique combination of a criminal sanction being applied before the fact of actual speech; the defendant is punished for speech he has not yet uttered. Unlike the approved schemes of prior restraint, the remedy is not a civil order barring future expression, but a criminal sanction imposed for intended future expression.

There is a further distinguishing factor between advance civil restraints and criminal conspiracy. The cases dealing with prior restraints have largely involved books or films. In such instances the proposed expression is in existence in a final form and can be carefully examined to see if its distribution or showing would in fact violate constitutional obscenity standards. Often, of course, this will not be true of the speech-conspiracy case; where the proposed communication is oral, there is nothing in existence by which to judge the illegality of the future expression except an inference based upon whatever evidence may be available concerning the defendant's expressed or unexpressed subjective intent. Even, for example, where there is a text of a proposed speech available, there is no certainty that it will be delivered as written. The judgment thus becomes wholly predictive, with the consequences not merely suppression of the speech, as would be true in the case of the usual prior restraint, but punishment for its mere intended delivery. ${ }^{185} \mathrm{It}$ is the most "prior" of prior restraints.

185 One factor the Court has emphasized in the prior restraint cases is the great need for prompt resolution of the issue of legality of the challenged speech; the absence 
It is possible to transform $S p o c k$, for example, into the classic prior restraint case. One wonders what the First Circuit would have done, or what the Supreme Court might have done, particularly after the Pentagon Papers Case, ${ }^{186}$ had Spock arisen as an injunctive action brought while the "conspiracy" remained wholly executory, that is, before any of the defendants had engaged in any actual counselling or aiding or abetting-if for example, the government had sought to enjoin issuance of the Call, or the holding of (or defendants' participation in) either the Boston or Washington rallies. ${ }^{187}$ It seems likely that the attempted suppression would have been labelled prior restraint and the requested relief denied, even if all the other facts-defendants' combination in the proposed action, etc.-had remained the same. At the very least, the government would have had to overcome the "heavy presumption against ... constitutional validity" which the Court has recently re-emphasized every "system of prior restraints of expression" must bear. ${ }^{188}$ The use of such language is totally foreign to the criminal conspiracy cases, though one wonders why. It is extremely difficult to understand why the same constitutional doubts that would apply in the case of a civil injunction should bear any less heavily in the criminal conspiracy case where the sanction is not merely prohibitive, but punitive. Nonetheless, the courts talk in terms of adequacy of governmental interest in the conspiracy context and fail to invoke the more stringent standard applicable in the less onerous civil context.

As noted, the civil injunction imposes no penalty, beyond the suppression itself, except if the court order is subsequently violated, and presumably any such order would, or should, be closely and carefully drawn with a specificity that minimized potential vagueness of application and gave clear warning of the limits beyond which the defendants could not go. Moreover, the order would presumably be directed to specific individuals for whom actual notice of it would be

of any fixed short period of time between initiation of the proceeding and final judgment threatens to moot the need or propitiousness of the expression itself. See cases cited note 183 supra. A similar danger obviously exists with respect to the criminal conspiracy case, with its usual delay between initiation of the proceedings (by information or before a grand jury) and the conclusion of trial and verdict. It would be difficult to abbreviate the required period within the kinds of limits the Court seems to consider necessary in prior restraint cases without potentially jeopardizing other constitutional rights of the accused.

186 New York Times Co. v. United States, 403 U.S. 713 (1971).

$187 \mathrm{~A}$ similarly close parallel-running the other way-would have been presented if the government, in the Pentagon Papers Case, note 186 supra, instead of seeking injunctive relief against the Times and Post, had brought a criminal conspiracy indictment against one of the papers and its employees charging them, prior to actual publication, with an illegal conspiracy to publish. One wonders whether the Court, though unwilling to allow an injunction at that stage, would nonetheless have condoned the criminal action.

$188 \mathrm{New}$ York Times Co. v. United States, 403 U.S. 713, 714 (1971), quoting Bantam Books, Inc. v. Sullivan, 372 U.S. 58, 70 (1963). 
a due process prerequisite to subsequent punishment. None of these protections is available in the conspiracy context, where vagueness is one of the major difficulties.

On a number of grounds then, criminal conspiracy-at least as used as a before-the-fact sanction on inchoate speech-presents an even stronger case for unconstitutionality than the usually invalid typical prior restraint. If real need there be, the injunctive prohibition, with proper procedural requirements met, would appear in many ways a preferable and less oppressive method of dealing with the unwanted and truly threatening speech than the prior criminal restraint.

\section{The "Hard" Case}

The preceding analysis has stressed the difficulty, in a speechconspiracy case, of judging the legality of what the defendant intends but has not yet done. Yet, one can at least hypothesize cases in which the difficulty is minimized-cases in which there is some apparently solid basis for determining the character of the defendant's proposed speech and appraising its probable effect on a specific audience for which it was designed. For example, one can suppose a situation in which the proposed advocacy was in the form of an already printed pamphlet or handbill admittedly prepared for use at a specific, already scheduled rally. One might additionally assume that there was independent evidence that the defendants intended that the distribution of the written message would help set off a riot, and that the actual text contained language which had a high probability of doing exactly that. Conjecture about the nature of the speech, the circumstances and manner of its delivery, and its possible or probable effect on a particular audience is either eliminated or considerably narrowed. ${ }^{189}$ Why, in such an instance, is not a prosecution for conspiracy to incite to riot an appropriate tool of effective law enforcement?

There are several possible answers. The first is that it might be reasonable to allow prosecution under the conspiracy rubric in that precise case. The facts are designed to state the strongest situation; they eliminate many of the objections to the use of conspiracy and do so in a context in which prosecution for a more substantive offenseactual incitement-is not available as an alternative. Yet there are strong countervailing reasons which militate against allowing the prosecution.

189 The hypothetical might be considered a variant of People v. Epton, 19 N.Y.2d 496, 227 N.E.2d 829, 281 N.Y.S.2d 162 (1967), cert. denied and appeal dismissed, 390 U.S. 29 (1968). Cf. Rockwell v. Morris, 9 N.Y.2d 791, 175 N.E.2d 162, 215 N.Y.S.2d 502 (1961). See also Kasper v. Brittain, 245 F.2d 92 (6th Cir.), cert. denied, 355 U.S. 834 (1957); Brewer v. Hoxie School Dist. No. 46, 238 F.2d 91 (8th Cir. 1956). 
First, primary justification for official intervention prior to actual dissemination of the defendants' message in this case is not punishment, but suppression of the speech and prevention of the probable riot. The legal weapon best designed to achieve this objective is not the criminal sanction, but a civil one, the injunction. This is the traditional prior restraint and carries with it a range of traditional objections; ${ }^{190}$ but the criminal charge is, in this instance, no less prior, brings objections of its own, and is ill-fitted to the particular need. While the defendants will lose the advantage of jury trial in an injunctive action, the overall result is likely to be less inhibiting, at least as to third parties whose situation is truly ambiguous, and the sanction will be more carefully tailored to the desired result. ${ }^{191}$ Once again, the rifle seems preferable to the shotgun, if those are the only choices and one or the other must be used. Moreover, compelling recourse to the civil sanction is more likely to result in a closer scrutiny of the real need to suppress the proposed speech at all. Tradition once again seems to play a significant role, but here a happy one, in that the injunctive prior restraint is viewed with a highly jaundiced constitutional eye; the presumption is at least said to be against constitutionality, rather than in favor of it, as appears to be true in the criminal case. ${ }^{192} \mathrm{~A}$ reasonable expectation is that the restraint would less often be imposed where unwarranted.

The second objection goes to the need for any sanction, criminal or civil. There would be no criminal option available at all if the pamphlet and its expected distribution represented the work of a single individual. With one person acting alone, there would be no basis for a conspiracy prosecution, and the authorities would have to await actual incitment. If society can take that risk in the case of one person,

190 See text accompanying notes $179-88$ supra.

191 The "inhibition" here should be distinguished from that usually involved in comparing prior civil restraints with subsequent criminal punishment. It is usually assumed that subseguent punishment is less a deterrent than a prior injunctive restriction; whether this premise is right or wrong may be disputable, but the presumed value of relying on post hoc punishment is that it occurs after the speech has been uttered. See, e.g., Kalven, The Supreme Court, 1970 Term, Forward: Even When a Nation Is at War, 85 Harv. L. Rev. 3, 34 (1971); Henkin, The Right to Know and the Duty to Withhold: The Case of the Pentagon Papers, 120 U. PA. L. Rev. 271, 278 (1971). When both the civil injunction and the criminal sanction are applied before the fact, it may be more likely that the former will lessen the chance of the speech occurring. To the extent that the criminal charge carries with it the certainty of punishment in the event of conviction, whether the speaker goes ahead or not, it arguably is no independent deterrent at all once there has been an indictment. Of course, if his words, when spoken, actually constitute incitement, he may later be prosecuted for that crime as well, i.e., the threat of subsequent punishment remains. It does seem clear though, that the threat of a beforethe-fact conspiracy prosecution would be more effectively and more broadly chilling of speech rights-both as to those who would speak and as to those who might be indicted as co-conspirators-than any threatened injunction.

192 See text accompanying note 188 subpra. 
how does the situation change so dramatically by simple addition of another, whose participation, for example, might have been limited solely to writing the inflammatory tract? It is possible to assume a group of fifty, of course, whose ability to achieve greater distribution of the tract might increase the risk, but it is also possible to assume, even given a "conspiracy," that the distribution will still be by one alone. The variant assumptions are really not very helpful. One suspects that responsible authorities, if moved by genuine fear of riot and minded to intervene at all, would resort to an injunction in any of these cases, be it one or more persons involved. ${ }^{193}$

Third, it is essential to remember that the case is a hypothetical one, constructed to raise the issues most sharply; it has not been found in the reported decisions. ${ }^{194}$ Significantly, the leading speech-conspiracy cases all involve situations in which allegedly illegal incitement or advocacy has already taken place. While less than conclusive, this raises doubt whether the case has arisen, or will ever arise, in the form suggested; more importantly, it suggests that if it has, other means (proper or improper) were found to deal with it and that the case to be made for the necessity of the conspiracy sanction in such an instance is highly suspect. At best, the situation appears extremely rare and its incidence hardly supports the need to preserve the highly questionable and dangerous "conspiracy to incite" for general use against the unexecuted agreement. ${ }^{195}$

Finally, the courts have made no attempt to limit the scope of speech-conspiracy to the facts of the hypothetical case; if they had, the entire matter would be far less troublesome. The rationale of the crime allows its broad-gauged use (and misuse) in situations where there is no real threat; experience with the "clear and present danger" standard in the World War I Espionage Act cases, and its variant in the Communist Party cases, gives faint hope of effective limitation. Were

193 Indeed, in analogous situations, this seems to be what was done. See cases cited note 189 supra.

194 The closest cases are similar to those cited in note 189 supra, and are distinguishable. Thus, in Epton, "inciting" and other preparatory conduct had already been engaged in and could have been used as the basis of the indictment. While Rockvell, Kasper, and Brewer involved an asserted need to stifle speech before utterance, none arose as a criminal charge of conspiracy. Rockwell involved issuance of a permit and the rest a judicial injunction, which, though speaking to the future, was based upon past words or conduct. In some of the cases, at least, the defendants' prior words or actions could presumably have been the foundation of a criminal prosecution-charging either conspiracy to incite or incitement-and the relevant authorities decided to so proceed.

195 The National Commission on Reform of Federal Criminal Laws has proposed the elimination of this kind of prosecution at least in a limited area. Their proposed code would not allow prosecution for conspiracy to advocate insurrection "unless [the defendant] engaged in conduct under circumstances in which there was a substantial likelihood that it would imminently produce [armed insurrection]." NationaI Comenissron on Reforar of Federal Crtaminal Laws, Proposed New Federai Crmanal Code $\S 1103(4)(a)$ (Final Report 1971). 
it otherwise-had the courts given promise of appropriate restriction on the use of conspiracy doctrine-the implications of allowing prosecution of the hypothetical case would be less ominous.

\section{E. The Remaining Justification}

With remarkable consistency, the courts have adhered to the doctrine that an agreement to engage in prohibited speech is itself punishable as a crime. Yet one is struck by the apparent fact that prosecution is invariably brought only after the allegedly illegal speech or advocacy has taken place.

Of course, it is possible to say that the likelihood of actual prosecution of an executory speech conspiracy is no more than a straw man; no such examples were discovered and, it might be suggested, the probability that any would arise is too self-evidently remote to be worthy of comment. This proves too much, however, for any concession that none have been or would be brought is also a concession either of impropriety or of the absence of any need to do so, or both. Whichever it may be, the justification-practical or theoretical-for use of conspiracy as a purely inchoate offense in the speech area is stripped of its foundation. To say that a prosecutor could not or would not frame a speechconspiracy case in which the offending words have not yet been uttered is a convincing declaration that to do so would be an abuse or that recourse to such an action is simply not essential to protection of society from incipient harm. The corollary of this conclusion is that the speech-conspiracy charge would be (is) used only where the illegal incitement or advocacy had already occurred and indictment for the more substantive offense was possible. But if prior illegal speech is viewed as either a practical or constitutional requirement of conviction, then the gravest doubt is cast on the propriety of the speech-conspiracy case altogether. The argument for use of conspiracy as a necessary device to thwart inchoate crime-here incitement or advocacy-fails because those offenses must have already occurred and prosecution for them is possible. The reasoning which would sustain use of conspiracy as an inchoate offense simply does not stand up when the charge is relied upon as an alternative to, or additional ground of, prosecution in the case of the executed conspiracy. When the illegal speech has already occurred, some other footing must be found to support continued use of the conspiracy charge; it can no longer be defended as necessary to prevent either realization of the offending speech or maturation of the threatened harm. The burden would thus seem to shift to those who would urge the necessity of conspiracy as an alternative or 
supplementary charge in the context of the completed substantive speech offense. There are several possible justifications.

First, to the extent that the completed offense represents only part of the conspiratorial design, it could be said that a charge of conspiracy was appropriate and necessary to thwart the still executory portions of the group plan. Indeed, Spock is arguably that precise situation-a case in which prosecution was brought not simply to punish the defendants for what they had already done, but to prevent continuation of their efforts to achieve as yet unrealized objectives of the combination. Even with this conception, however, the argument assumes the conclusion, since it fails to explain why prosecution for the already extant substantive offenses is inadequate to the task. It is difficult to understand why, since indictable substantive offenses had already occurred, conviction for those crimes-counselling and aiding and abetting-would not prove sufficient to forestall similar conduct in the future; and if it would not, what basis is there to think that putting a conspiracy label on the case would have any different effect? In addition, another central difficulty remains, that of prosecuting the defendants for the unexecuted portions of the agreement which must be read in the light of speech still to occur.

Another reason which might be advanced to support application of the conspiracy doctrine to speech is drawn from the general justification for its application in other contexts where the substantive offense has already occurred. Analogizing to the organized crime case, for example, it might be argued that the conspiracy net is essential to catch those who because of their peripheral or less direct participation in the completed speech crime would not otherwise be subject to conviction. The answer seems self-evident. Those who are neither direct participants in speech crimes nor punishable under stricter standards as accomplices or aiders and abettors probably should not be punished at all. ${ }^{196}$ The potential gains-a highly doubtful increase in deterrence, and punishment of a few additional peripheral figures for speech crimes

${ }^{106} \mathrm{~A}$ prosecution for aiding and abetting, or being an accomplice to a speech crime, while preferable to use of a conspiracy charge, is also not without problems. Indeed, some of the same difficulties of conspiracy exist with regard to these other offenses, albeit to a lesser degree. The aiding and abetting concept partakes of vagueness and has been construed to allow relaxation of the hearsay rule to permit, on an "agency" rationale, introduction of the admissions of one defendant against another. See, e.g., United States v. Dowery, 334 F.2d 787 (7th Cir. 1964), cert. denied, 379 U.S. 933. For reasons similar to those advanced here with respect to conspiracy, it might be argued, and perhaps should be, that no accomplicelike liability should be permitted at all in conjunction with speech crimes. Whatever their problems, however, these crimes of direct complicity-aiding and abetting and being an accomplice-are highly preferable to conspiracy. Commission of the substantive offense is a prerequisite to their use and thus there is no element of inchoacy. The underlying concepts, while not as specific as they might be, are, among other things, considerably less elastic than conspiracy and the element of vicarious liability is greatly diminished, as are the procedural advantages to the prosecution. 
- seem clearly outweighed by the costs-potential prosecutorial abuse, chilling of speech and associational rights, and possible conviction of innocent persons at the fringe of constitutional protection, the selfsame group for whom the courts express such concern. To suffer, for such questionable advantage, the vagueness and flexibility of speechconspiracy, with its loose evidentiary and trial rules, seems inconsistent with the demands of the first amendment; the speech area is the very one in which we should least want to cast the broadest net of criminality and in which one would expect procedural requirements to be among the strictest, not the most lenient. ${ }^{197}$

In short, then, if actual illegal speech is not an essential element of the speech-conspiracy, all such prosecutions partake of the vagaries and vagueness of predictive criminality, the first amendment notwithstanding; there is no distinction to be drawn between the executed and the unexecuted speech-conspiracy and both are equally punishable. Alternatively, if there must be some actual illegal speech activity before prosecution will properly lie, then the stated rationale of the crime must be found elsewhere than in the loose litany of the need for intervention to prevent assertedly illegal speech, for it has already occurred. Moreover, some explanation must be forthcoming as to why prosecution for the direct speech offense is not sufficient to protect the public interest. It is time the courts demonstrated candor in describing the offense and declaring its requisite elements.

\section{CoNCLUSION}

Three important interests are involved in the appraisal of conspiracy doctrine as applied to speech. Each has a strong claim to recognition. The first is society's interest in preventing or punishing the occurrence of substantive evil-the threatened consequences of advocacy which does in fact pose a real danger. Second is the need to assure that individual defendants are adequately insulated from unwarranted prosecution and conviction and that their individual rights (procedural and substantive) are not denied or unduly threatened. Finally, there is the broader first amendment interest, the need to safeguard the constitutional rights of free speech and association, both of the individual defendants and of others; the risk is the loss to society - the body politic-flowing from inhibition of the very discourse which the first amendment was intended to protect and foster.

197 Speiser v. Randall, 357 U.S. 513, 521 (1958), is again relevant:

[S]ince the validity of a restraint on speech in each case ... depends on careful analysis of the particular circumstances, the procedures by which the facts of the case are adjudicated are of special importance and the validity of the restraint may turn on the safeguards which they afford. 
It is because speech-conspiracy so obviously intertwines these related, but conflicting, concerns that the problems inhering in its use have sometimes seemed so intractable. Resolution of the conflict, however, has almost always been in favor of suppression of speech. That resolution is unwarranted.

Use of conspiracy in the speech area does not appreciably foster society's interest in law and order. It is rarely, if ever, applied to the executory speech-conspiracy. Viewed as a device designed to forestall incipient harm, it is of doubtful efficacy. Employed after commission of a speech crime, it is unnecessary, though doubtless advantageous to prosecutors.

However utilized, conspiracy doctrine imports pervasively vague concepts into the speech area and needlessly inhibits the exercise of constitutional rights. Its invocation carries with it concepts of vicarious liability, leads to procedural laxities, and invites prosecutorial overreaching. Procedural protections devised to guard against such consequences in the ordinary criminal conspiracy case are wholly inadequate in the speech area where the possibility of bias is magnified by the fact that the defendants are characteristically unpopular dissenters. And the very vagueness of the speech-conspiracy offense drastically limits the possibility of either meaningful control of juries or of effective appellate review.

The combination of conspiracy with speech crimes should be held unconstitutional. Reliance on steps short of this seem inadequate to meet the manifold problems engendered by the crime. Little more, if anything, can be added to the intent element as elaborated in Scales, Noto and Spock. Enlarging the substantive content and significance of the overt act, even if made necessary in all cases, is futile. If the overt act must be the illegal speech itself, then the crime has ceased to be inchoate and prosecution for incitement is possible; if the overt act must be something other than speech, but may still be innocent in itself (like purchasing paper to print a leaflet), it adds little, if anything; ${ }^{108}$ if it must be criminal, then prosecution may be brought to deal with that conduct. Judicially imposed restrictions on the applicability in speech cases of the loose procedural and evidentiary rules usually available to the prosecution in a conspiracy case would go to but one aspect of the dangers inhering in the charge.

Denying the government the use of the conspiracy charge in

198 In Epton v. New York, 390 U.S. 29, 30 (1968) (concurring and dissenting opinions), Justices Stewart and Douglas raised the question of whether it is ever proper to rely on protected speech as an overt act in any conspiracy case. Even were the answer negative, it would still not meet the underlying difficulties peculiar to conspiracy to commit a speech crime. 
speech cases will have a number of beneficial effects. ${ }^{199}$ In $S p o c k$, for example, the prosecution would have been obliged to charge "aiding and abetting" or "counselling" or "inciting," i.e., the direct speech crimes. Of course, Goodman and Coffin might still have been convicted of those offenses. But elimination of the conspiracy element would have reduced the asserted crime to something much more concrete in both a legal and a lay sense; the vague, polymorphous aspect of conspiracy would have given way to a more tangible and manageable indictment. There would have been a single level of definitional uncertainty, that flowing from the imprecision of the constitutional line between legal and illegal speech. As difficult as that distinction may be, it is still a more workable standard than that which results when it is overlaid with the shaded contours of conspiracy. There would have been a clearer focus on the existence, vel non, of a real danger as posed by the specific speech of the specific defendants, rather than by the amorphous agreement. The evidence would have been more narrowly constricted and presented in a more orderly fashion. The jury would have been presented with a clearer case under simpler instructions and there would have been less chance of error (in procedure or verdicts) at trial and a better opportunity for correction on appeal. There might well have been fewer actual defendants and certainly fewer potential defendants. Guilt would have been personal, not vicarious or associational, and each defendant would have been liable only for what he said; there would have been little reason to fear liability for the words or actions of others. There would have been no chance of conviction for what the jury believed any of the defendants might have intended

199 One possible response to invalidation of the use of speech-conspiracy as a criminal offense is that prosecutors-desirous of retaining untoward trial advantagewould simply reframe indictments to charge a conspiracy to commit the ultimate substantive offense which the defendants' allegedly inciting speech was designed to produce. Thus, in lieu of an indictment for conspiracy to incite riot, the charge could become conspiracy to riot. But, if words are to have meaning, the variation must have substantive import and work a change in the nature of the proof required. It should not be enough to demonstrate merely that the defendants intended to make a speech or distribute literature; it would have to be shown that they intended to do more-to make or supply weapons, for example, or to participate in the riot themselves-and that these were the objectives of their agreement.

It has been suggested that another way of dealing with this assumed prosecutorial response would be for the courts to look through the face of indictments to determine whether what is really being charged is a conspiracy to commit a speech crime. See Note, Conspiracy and the First Amendment, 79 YALE L.J. 872, 890-93 (1970). It is possible that where overt acts are required and charged, this could be done, at least by rejecting those indictments in which the only such acts alleged are speech. Beyond this, however, the suggestion raises problems. In most cases, it will be extremely difficult, if not impossible, to make the requisite judgment before the government has put on its case, i.e., before trial. Once the proceeding has moved to that stage, the issue becomes one of adequacy of proof, not adequacy of the pleading. The underlying need, then, is for courts to insist that the government show that there was a conspiracy to commit the substantive offense, not merely to incite its occurrence. 
to say in the future; punishment would clearly have been for words already spoken.

The court in Spock could presumably have found a much more satisfactory basis for distinguishing among the various defendants and the permissibility of findings of guilt as to each (assuming that all would have been indicted). The court would not have been constrained to direct acquittal or allow retrial on such palpably subjective and unsatisfactory grounds as it did.

In sum, the consequence would have been a fairer result and a greater clarity in the law-a more assured basis for foreseeing the potentiality of criminal conduct and a reduced danger of chilling the rights of others who might see themselves as potential defendants in a similar situation. The first amendment requires no less. 